\title{
Highly variable Pliocene sea surface conditions in the Norwegian Sea
}

\author{
Paul E. Bachem ${ }^{1}$, Bjørg Risebrobakken ${ }^{1}$, Stijn De Schepper ${ }^{1}$, and Erin L. McClymont ${ }^{2}$ \\ ${ }^{1}$ Uni Research Climate, Bjerknes Centre for Climate Research, Jahnebakken 5, 5007 Bergen, Norway \\ ${ }^{2}$ Department of Geography, Durham University, Durham, DH1 3LE, UK \\ Correspondence to: Paul E. Bachem (paul.bachem@uni.no)
}

Received: 4 December 2016 - Discussion started: 21 December 2016

Revised: 30 June 2017 - Accepted: 10 July 2017 - Published: 11 September 2017

\begin{abstract}
The Pliocene was a time of global warmth with small sporadic glaciations, which transitioned towards the larger-scale Pleistocene glacial-interglacial variability. Here, we present high-resolution records of sea surface temperature (SST) and ice-rafted debris (IRD) in the Norwegian Sea from 5.32 to $3.14 \mathrm{Ma}$, providing evidence that the Pliocene surface conditions of the Norwegian Sea underwent a series of transitions in response to orbital forcing and gateway changes. Average SSTs are $2{ }^{\circ} \mathrm{C}$ above the regional Holocene mean, with notable variability on millennial to orbital timescales. Both gradual changes and threshold effects are proposed for the progression of regional climate towards the Late Pliocene intensification of Northern Hemisphere glaciation. Cooling from 4.5 to $4.3 \mathrm{Ma}$ may be linked to the onset of poleward flow through the Bering Strait. This cooling was further intensified by a period of cool summers due to weak obliquity forcing. A $7^{\circ} \mathrm{C}$ warming of the Norwegian Sea at $4.0 \mathrm{Ma}$ suggests a major increase in northward heat transport from the North Atlantic, leading to an enhanced zonal SST gradient in the Nordic Seas, which may be linked to the expansion of sea ice in the Arctic and Nordic Seas. A warm Norwegian Sea and enhanced zonal temperature gradient between 4.0 and 3.6 Ma may have been a priming factor for increased glaciation around the Nordic Seas due to enhanced evaporation and precipitation at high northern latitudes.
\end{abstract}

\section{Introduction}

The Pliocene (5.333 to $2.58 \mathrm{Ma}$ ) was the last epoch with extended warmth before the onset of the Pleistocene glacialinterglacial cycles of expanding and melting Northern Hemi- sphere ice sheets (Lisiecki and Raymo, 2005; Fedorov et al., 2013; Herbert et al., 2016). Evidence for early small-scale glacial build-up in the Northern Hemisphere is based on IRD deposited from Greenland between 38 and $30 \mathrm{Ma}$ (Eldrett et al., 2007) and at 9.5 to $7.0 \mathrm{Ma}$ (Wolf and Thiede, 1991). Further isolated instances of glaciation on eastern Greenland have likely occurred since 7.0 Ma (Larsen et al., 1994), until large-scale glacial build-up is signaled by greatly increased IRD influx during the Late Pliocene (Jansen et al., 2000; St. John and Krissek, 2002). Small-scale ice rafting has been reported from the Norwegian Sea since the Miocene (Fronval and Jansen, 1996). This long history of small-scale glaciation, likely regionally confined, underlines the importance of a closer investigation of the Pliocene Northern Hemisphere climate in order to understand the transition towards large-scale Northern Hemisphere glaciation (NHG), including the growth of ice sheets. Striated IRD suggesting Pliocene glaciations has been reported in sediments west of Scandinavia at 4.9 to $4.8,4.0$, and $3.3 \mathrm{Ma}$ (Jansen et al., 1990; Jansen and Sjøholm, 1991). A statistically significant increase in global ice volume from $3.6 \mathrm{Ma}$ was noted by Mudelsee and Raymo (2005), who consider this to be the marker for the onset of NHG. Furthermore, a large increase in IRD influx in the North Atlantic (Kleiven et al., 2002), and a crash of productivity in the North Pacific (Haug et al., 2005), indicated an important threshold towards intensified Northern Hemisphere ice build-up at ca. 2.7 Ma.

The processes that initiated these regional glaciations and the overall progression towards the Late Pliocene intensification of NHG remain under discussion. The main hypotheses are long-term changes in the atmospheric $\mathrm{CO}_{2}$ concentration, changes in oceanic gateways and circulation, and 


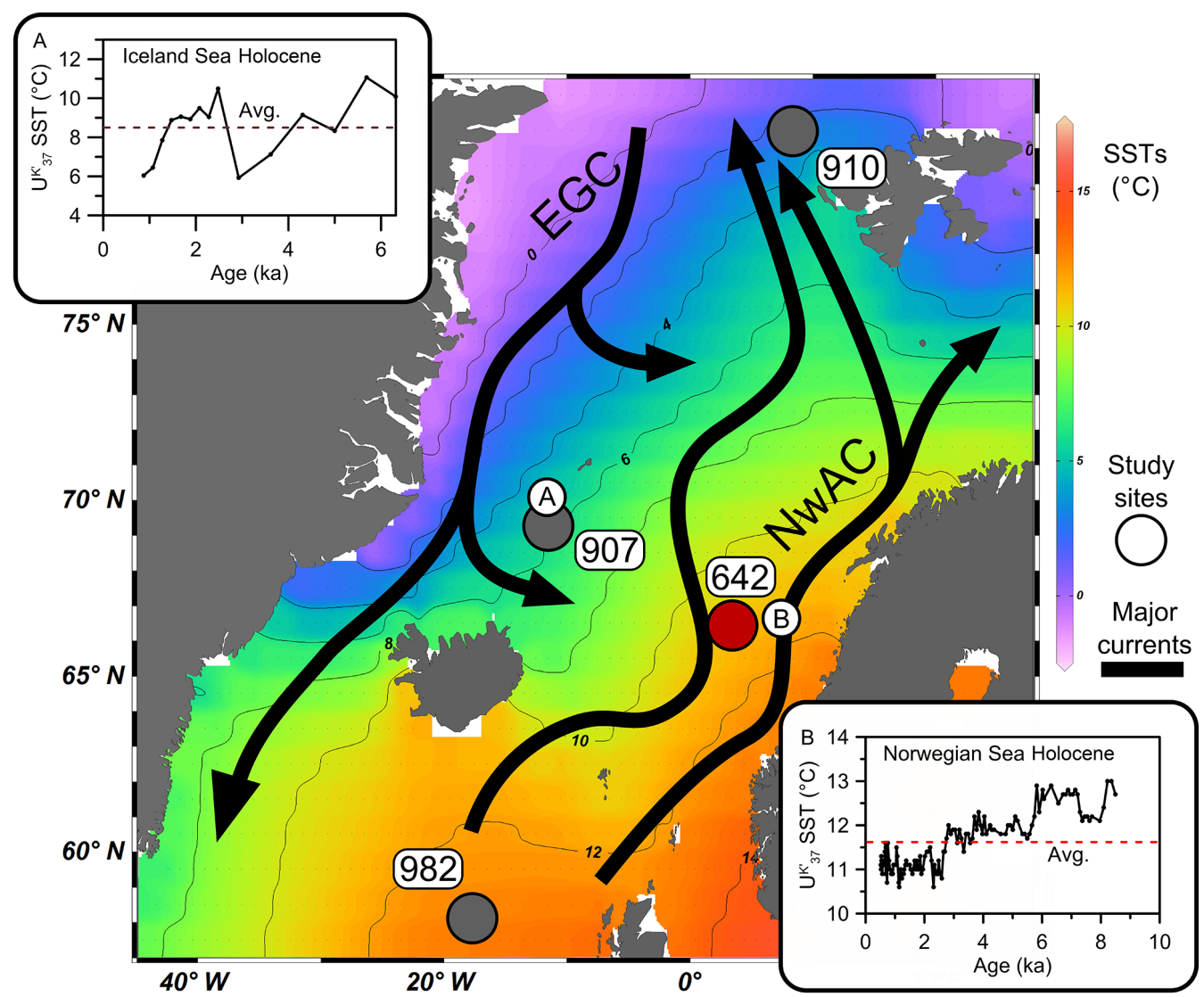

Figure 1. Nordic Seas, showing simplified modern surface currents and summer temperatures (JAS, World Ocean Atlas). NwAC: Norwegian Atlantic Current; EGC: East Greenland Current. The study site, ODP Hole 642B, is marked by a red circle. Pliocene sites referred to in the text (ODP Sites 907, 910 and 982) are marked by grey circles. The two sites that provide Holocene SST averages for comparison are marked with small white circles. Holocene SST data are shown in inserts (A: GS15-198-62 MC-A, this study, Table 1; B: MD95-2011, Calvo et al., 2002), with dashed lines indicating averages.

changes in orbital forcing. Recently Schreck et al. (2013) and De Schepper et al. (2015) promoted the importance of the Nordic Seas in priming the Northern Hemisphere for glaciation through the establishment of the East Greenland Current (EGC) and the modern Nordic Seas oceanographic pattern (Fig. 1) around 4.5 Ma. The establishment of the cold EGC, as a potential response to changes in the ocean circulation through the Bering Strait, has been considered important for large-scale glaciation of Greenland because the EGC thermally isolates Greenland from the warm waters transported northward in the Norwegian Atlantic Current (NwAC) (Bohrmann et al., 1990; Sarnthein et al., 2009; De Schepper et al., 2015).

A strengthening of the oceanic heat and moisture transport to high latitudes (Macdonald and Wunsch, 1996), in conjunction with the thermally isolated Greenland ice sheet (Driscoll and Haug, 1998), likely affected the onset of NHG (Raymo et al., 1996; Ravelo and Andreasen, 2000). The mechanisms and their impacts are, however, continuously debated. Some studies have proposed that increased northward heat transport led to increased high-latitude precipitation and ice build-up (Driscoll and Haug, 1998; Haug and Tiedemann, 1998), while others conclude that northward heat transport had very little (Lunt et al., 2008) or even the opposite effect, possibly delaying NHG by heating the high northern latitudes (Klocker et al., 2005). Stepwise strengthening of the Atlantic Meridional Overturning Circulation (AMOC) during the Pliocene (Haug and Tiedemann, 1998; Steph et al., 2006,2010 ) has been proposed. Although deep-water proxy datasets from the Caribbean support the hypothesis that the AMOC strengthened during the Early Pliocene (Steph et al., 2010) and during the mid-Piacenzian (ca. 3.3 to 3.0 Ma; Raymo et al., 1996), it has been argued that this does not indicate an Atlantic-wide strengthening of the overturning circulation. For example, not all benthic records from the Atlantic show the expected responses, e.g., $\delta^{13} \mathrm{C}$ enrichment, to a significant increase in AMOC intensity during the Early Pliocene (Bell et al., 2015). A stable AMOC during periods of intense Atlantic climate change has been reported by Bradtmiller et al. (2014) for transition into the Holocene and 
by Böhm et al. (2015) for the last glacial cycle, with casts doubt on whether strong AMOC variability can be expected during the warmer Pliocene. Alternative to the idea that a shift in the AMOC was responsible for high-latitude climate variability, and the eventual onset of intensified NHG, it has been proposed that the sill depth of the Greenland-Scotland Ridge (GSR) had a major impact on the climate of the Nordic Seas, with deeper water over the GSR entailing higher SSTs in the Nordic Seas according to model studies (Hill, 2015; Robinson et al., 2011).

In contrast to the suggestion that a strengthened AMOC and tectonic shifts were important for glacial growth at high northern latitudes, a modeling study by Klocker et al. (2005) indicated that strengthening of the AMOC would lead to decreased snowfall at high northern latitudes, despite any potential increase in precipitation. These authors concluded that AMOC change is a less effective driver of NHG than changes in orbital parameters. The configuration of the orbital parameters as a decisive timing factor of NHG around 2.7 Ma has also been suggested by Maslin et al. (1998), who proposed that an extended period of high-amplitude obliquity variability may have supported the preservation of ice through summer, but this mechanism also requires low enough atmospheric $\mathrm{CO}_{2}$ concentrations. Evidence exists for above Holocene (ca. 270 ppm; Indermühle et al., 1999) atmospheric $\mathrm{CO}_{2}$ concentrations during most of the Pliocene, with a decreasing trend towards the Late Pliocene (Pliocene $\mathrm{CO}_{2}$ estimates range between ca. 300 and 500 ppm; Bartoli et al., 2011; Martínez-Botí et al., 2015; Pagani et al., 2010; Seki et al., 2010). The decreasing atmospheric $\mathrm{CO}_{2}$ concentration has also been proposed as the cause for gradual global cooling which led to the expansion of Northern Hemisphere ice sheets during the Late Pliocene (e.g., Lunt et al., 2008; Martínez-Botí et al., 2015).

It is unclear in which way changes in atmospheric $\mathrm{CO}_{2}$ concentration, ocean heat transport, and orbital variability interacted at high northern latitudes, and whether the cooling of the Northern Hemisphere and the growth of ice sheets proceeded gradually or through more rapid transitions. Different regional patterns and timings of sea surface temperature (SST) decreases are recorded at a global scale since 4.0 Ma (Ravelo et al., 2004), with only a certain subset of sites, mainly in modern upwelling zones, showing a common trend of cooling starting at 4.0 Ma (Fedorov et al., 2013). The only existing sub-orbitally resolved Pliocene (5.1 to $3.1 \mathrm{Ma}$ ) climate records from the Norwegian Sea, based on the stable isotope composition of planktic and benthic foraminifers, indicate a series of distinct changes of water mass density and ventilation proposed to be driven by a combination of gateway changes and orbital forcing (Risebrobakken et al., 2016), but the authors also noted a potential impact of diagenetic overprinting which may complicate the recorded climate signals in planktic foraminifers. A recently published $\mathrm{U}_{37}^{K^{\prime}}$ SST record from the Iceland Sea shows variable surface conditions throughout the Pliocene (Herbert et al., 2016) that indicate overall above-modern temperatures, an Early Pliocene stepwise cooling trend and Late Pliocene warming. Variable but overall warm SSTs have also been reported from the North Atlantic, in the pathway of water masses that in modern-day flow into the Norwegian Sea (Lawrence et al., 2009; Herbert et al., 2016).

Here, we present high-resolution $\mathrm{U}_{37}^{K^{\prime}}$ SSTs, $\mathrm{C}_{37: 4}$ alkenone percentages $\left(\% \mathrm{C}_{37: 4}\right)$, and IRD counts from ODP Hole 642B in the Norwegian Sea (Fig. 1) across the 5.32 to 3.14 Ma time interval. Sea surface temperatures and $\% \mathrm{C}_{37: 4}$ provide insights into the changing properties of the surface water masses in the western Nordic Seas, while the IRD record indicates changes in the behavior of glacial margins extending to the Nordic Seas. The records from ODP Hole 642B provide insight on whether Pliocene climate variability on tectonic (>100 kyr) and orbital timescales (20 to $400 \mathrm{kyr}$ ) was important for establishing favorable conditions for sporadic Northern Hemisphere glaciation during the Early Pliocene (De Schepper et al., 2014), and for increasingly widespread glaciation during the Late Pliocene (Kleiven et al., 2002; Shackleton et al., 1984).

\section{Study area and present-day oceanographic conditions}

Two major surface currents dominate the Nordic Seas (Norwegian Sea, Greenland Sea, and Iceland Sea), the Norwegian Atlantic Current (NwAC) and the East Greenland Current (EGC) (Fig. 1), setting up distinct meridional and zonal gradients of SSTs and salinity (e.g., Blindheim and Østerhus, 2005). The NwAC is supplied by the North Atlantic Current (NAC) with warm and saline Atlantic water $\left(>3{ }^{\circ} \mathrm{C}\right.$, $>35$ psu; Mauritzen, 1996). It flows in two bathymetrically steered branches over the Norwegian shelf and the Norwegian Basin. Moving northward the Atlantic water masses of the NwAC lose heat due to exchange with the atmosphere. The NwAC bifurcates at the Barents Sea, and again when the NwAC reaches the Fram Strait, where parts of its water masses submerge into the Arctic Ocean, while the majority of the Atlantic water is deflected westward and submerged southward below the surface of the EGC. The surface of the EGC is composed of cold and relatively fresh polar water ( 0 to $0.5^{\circ} \mathrm{C}, 34.8$ to $34.9 \mathrm{psu}$; Mauritzen, 1996) which travels southward through the Fram Strait. The polar water flows southward along the Greenland shelf and exits the Nordic Seas through the Denmark Strait between Greenland and Iceland. Parts of the polar water are deflected into the Greenland Sea and the Iceland Sea, where they form part of the Nordic Seas deep water, feeding the North Atlantic deep water (e.g., Mauritzen, 1996). The remainder of the deep water is a mixture of deflected Atlantic water as well as recirculated Atlantic water that passed through the Arctic Ocean. In the central Nordic Seas, between the polar water in the west and the Atlantic water in the east, a mixed region of Arctic water 
extends (Blindheim and Østerhus, 2005). The Arctic water is bounded by the polar front in the west and the Arctic front in the east.

\section{Materials and methods}

\subsection{Site, samples, and age model}

In this study, we investigate sediments from ODP Hole 642B (Eldholm et al., 1987), using material dated to the Pliocene from 85.66 to $66.99 \mathrm{~m}$ below sea floor (m b.s.f.). The study site is situated on the Vøring Plateau $\left(67^{\circ} 2^{\prime} \mathrm{N}, 2^{\circ} 9^{\prime} \mathrm{E}\right)$ at a water depth of $1280 \mathrm{~m}$. Presently Hole 642B lies beneath the western branch of the NwAC and experiences warm summer SSTs averaging $10.2^{\circ} \mathrm{C}$ (Locarnini et al., 2013). We apply the new Hole 642B age model developed by Risebrobakken et al. (2016), based on the magnetostratigraphy of Bleil (1989) updated to the ATNTS2012 timescale (Hilgen et al., 2012), and further constrained for the time interval between 4.147 and $3.140 \mathrm{Ma}$ by tuning the benthic oxygen isotope record from Hole 642B (Cassidulina teretis) to the global $\delta^{18} \mathrm{O}$ stack of Lisiecki and Raymo (2005). This age model gives the studied material an age range from 5.321 to 3.141 Ma.

Core-top samples from Hole 642B and Site 907 were not available for $\mathrm{U}_{37}^{K^{\prime}}$ analysis. We compare the Pliocene SSTs with Holocene mean $\mathrm{U}_{37}^{K^{\prime}}$ SSTs given by the same method at nearby sites (Fig. 1) to include more of the variability that exists within the present warm period ( 0 to $10 \mathrm{ka}$ ) when comparing to Pliocene measurements, where each value represents a much longer time span (hundreds to thousands of years) than that covered by any instrumental time series. Furthermore, this approach gives the PlioceneHolocene difference between consistent methods instead of mixing temperature information from instrumental measurements with proxy reconstructions. We present new Holocene averaged $\mathrm{U}_{37}^{K^{\prime}}$ SST data from the Iceland Sea (Site GS15198-62 MC-A, $70^{\circ} 01^{\prime} \mathrm{N}, 13^{\circ} 33^{\prime} \mathrm{W}, 1423 \mathrm{~m}$ depth; Fig. 1, this study), alongside previously published Holocene averages for Norwegian Sea site MD95-2011 (Calvo et al., 2002). Both datasets were generated using the same methods as for Hole 642B. For core GS15-198-62 MC-A, the Holocene is identified to the upper $26 \mathrm{~cm}$ below seafloor based on radiocarbon dates (Table 1) (Saint-Macary, 2016; unpublished master intern report).

\subsection{Alkenone-based sea surface temperature reconstructions}

All alkenone measurements were produced at the biomarker laboratory of the Department of Geography, Durham University, UK. Alkenone-derived SSTs were measured from 333 sediment samples taken at ODP Hole 642B, extending the record of 59 samples spanning 3.264 to 3.140 Ma previously published for this site by Bachem et al. (2016a).
Alkenones were extracted from freeze-dried samples ( 1 to $2 \mathrm{~g})$ using $12 \mathrm{~mL}$ of dichloromethane and methanol $(3: 1$ $v / v$ ) in a CEM MARS microwave, following the protocol of Kornilova and Rosell-Melé (2003). Extraction was aided by heating to $70^{\circ} \mathrm{C}$ over $2 \mathrm{~min}$, holding the temperature for $5 \mathrm{~min}$, and cooling below $30^{\circ} \mathrm{C}$ before further processing. Lipids were recovered by centrifuge (to separate from sediments) and rotary evaporator (to remove solvent). Silica column chromatography was used with hexane, DCM, and methanol as eluents to separate the ketones, including alkenones, from other extracted lipids (non-polar and polar compounds). We quantified the alkenones using a gaschromatograph fitted with a flame ionization detector (FID; Thermo Scientific Trace 1310). Hydrogen was used as a carrier gas. Injector temperature was set to $280^{\circ} \mathrm{C}$, FID temperature to $350^{\circ} \mathrm{C}$. After injection, temperatures were increased from 70 to $170^{\circ} \mathrm{C}$ at $12^{\circ} \mathrm{C} \mathrm{min}^{-1}$, then to $310^{\circ} \mathrm{C}$ at $6^{\circ} \mathrm{C} \mathrm{min}^{-1}$ and held at that temperature for $40 \mathrm{~min}$. The $\mathrm{U}_{37}^{K^{\prime}}$ index was calculated according to Prahl and Wakeham (1987). We apply the Müller et al. (1998) calibration to convert data from the $\mathrm{U}_{37}^{K^{\prime}}$ index to SSTs. While this calibration of $\mathrm{U}_{37}^{K^{\prime}}$ to SSTs does not include sample sites further north than $60^{\circ} \mathrm{N}$, it has been shown to provide reliable results in the Norwegian Sea during the Holocene) (e.g., Calvo et al., 2002; Risebrobakken et al., 2011). The resulting SSTs are considered to represent the temperature of the surface mixed layer, with best fit at $0 \mathrm{~m}$ (Müller et al., 1998). For the Holocene data from Site GS15-198-62 MC-A the sample preparation was performed as for $642 \mathrm{~B}$, then chemical ionization mass spectroscopy was used to detect the weaker alkenone signals, following the method of Rosell-Melé et al. (1995).

It has been suggested that there is a likely bias towards summer temperatures in $\mathrm{U}_{37}^{K^{\prime}}$ SST data in the Nordic Seas because of the low insolation during the winter months at high latitudes (Risebrobakken et al., 2011). Nevertheless, there is some doubt about the preservation of seasonally biased alkenone production signals in sediments because a clear seasonal signal is not recorded in the alkenone flux at lower depths in the water column (Rosell-Melé and Prahl, 2013). Assuming that a summer bias is inherent in our SST record due to the low primary productivity of the Nordic Seas during winter (Andruleit, 1997; Baumann et al., 2000), we suggest that high-latitude $\mathrm{U}_{37}^{K^{\prime}}$ SST data may show the evolution of the summer mixed layer, and consequently respond to changes in the intensity of summer insolation, as it has been reported for the Holocene (Risebrobakken et al., 2011). This interpretation is supported by the late Holocene $\mathrm{U}_{37}^{K^{\prime}}$ SSTs being more comparable to instrumentally recorded summer temperatures at the studied sites than to annual mean temperatures (Locarnini et al., 2013).

In previously published $\mathrm{U}_{37}^{K^{\prime}}$ SST records from ODP Site 907 in the Iceland Sea, no summer bias is assumed (Herbert et al., 2016; De Schepper et al., 2015; Schreck et al., 
Table 1. AMS ${ }^{14} \mathrm{C}$ dates from GS15-198-62MUC-A, and calibrated calendar ages. All dates were calibrated using Calib 7.10 (Stuiver et al., 2017), the Marine13 calibration dataset, and a $\Delta R=0 \pm 50$. N. pachyderma $=$ Neogloboquadrina pachyderma. Median probability ages are used as tie points when calculating the age model, based on linear interpolation between these tie points.

\begin{tabular}{|c|c|c|c|c|c|c|c|}
\hline $\begin{array}{l}\text { Depth } \\
(\mathrm{cm})\end{array}$ & Lab ID & Dated material & ${ }^{14} \mathrm{C}$ age & $\begin{array}{r}\text { Calibrated age } \\
\text { range (BP) } \\
( \pm 1 \sigma, \Delta R=0 \pm 50)\end{array}$ & $\begin{array}{r}\text { Relative } \\
\text { probability }\end{array}$ & $\begin{array}{r}\text { Calendar age } \\
\text { (median probability) } \\
\text { yr BP (1950) }\end{array}$ & Reference \\
\hline $5-5.5$ & BETA459130 & N. pachyderma & $2010 \pm 30$ & $1510-1660$ & 1 & 1576 & This study \\
\hline $10-10.5$ & BETA459131 & N. pachyderma & $2830 \pm 30$ & $2503-2685$ & 1 & 2581 & This study \\
\hline $15-15.5$ & BETA459132 & N. pachyderma & $5630 \pm 30$ & 5945-6104 & 1 & 6034 & This study \\
\hline $20-20.5$ & BETA459133 & N. pachyderma & $8310 \pm 30$ & $8780-8970$ & 1 & 8864 & This study \\
\hline $42.5-43$ & BETA432223 & N. pachyderma & $1700 \pm 60$ & $19905-20143$ & 1 & 20023 & $\begin{array}{l}\text { Saint-Macary, 2016, } \\
\text { unpublished master } \\
\text { intern report }\end{array}$ \\
\hline
\end{tabular}

2013). Considering the close meridional proximity of ODP Hole $642 \mathrm{~B}\left(67^{\circ} 13.5^{\prime} \mathrm{N}\right)$ and ODP Site $907\left(69^{\circ} 15.0^{\prime} \mathrm{N}\right)$, and the similar summer peak in coccolithophorid productivity in both regions (Baumann et al., 2000), in addition to the correspondence between late Holocene SSTs and instrumentally recorded summer temperatures, it is likely that any seasonal bias would be similar in both records, and hence that the reported SSTs are comparable in this regard, even though these sites presently lie in very different water masses (Fig. 1).

The tetra-unsaturated $\mathrm{C}_{37: 4}$ alkenones were quantified as a percentage of the three $\mathrm{C}_{37}$ alkenones $\left(\mathrm{C}_{37: 2}, \mathrm{C}_{37: 3}, \mathrm{C}_{37: 4}\right)$. The $\mathrm{C}_{37: 4}$ alkenone is produced mainly in cool water masses (e.g., Rosell-Melé et al., 1994) and has been suggested to indicate the influence of fresh water when it exceeds $5 \%$ (Rosell-Melé, 1998). In the Nordic Seas cool and fresh water masses are closely linked (Bendle et al., 2005; Sikes and Sicre, 2002), which is why a distinct separation of a temperature and salinity response of this proxy may not be possible. We consider increases of $\% \mathrm{C}_{37: 4}$ to be a supporting indicator for an increased influence of both colder and fresher water masses (Bendle et al., 2005; Filippova et al., 2016), in particular at instances when IRD peaks coincide with $\mathrm{C}_{37: 4}$ peaks. An alternative approach exploits the co-variation of SST and salinity in the Nordic Seas, as well as the presence of specific surface water masses (Bendle et al., 2005) which showed that elevated $\% \mathrm{C}_{37: 4}$ and low SSTs occurred in colder and less saline Arctic waters, and this is the interpretation we apply here. Instances where IRD peaks coincide with $\% \mathrm{C}_{37: 4}$ would also lend support to the interpretation of cooler and potentially less saline surface water masses.

\subsection{Ice-rafted debris}

Ice-rafted debris grains $>150 \mu \mathrm{m}$ were counted visually in 539 samples using a binocular microscope, with an average sample resolution of $3.6 \mathrm{kyr}$. This extends the record of 94 samples published by Bachem et al. (2016a) for the 3.264 to $3.140 \mathrm{Ma}$ time interval. A previous study was performed on Hole 642B sediments of the $>125 \mu \mathrm{m}$ fraction by
Jansen and Sjøholm (1991), who achieved an average sample resolution of $14.5 \mathrm{kyr}$. As noted in Bachem et al. (2016a), this approach misses the IRD of smaller grain sizes, but the $>150 \mu \mathrm{m}$ IRD fraction is sufficient to correlate the presence and variability of IRD in the Nordic Seas region to SSTs. The record of IRD provides data regarding the influx of coarse terrestrial material. This merely indicates the existence of calving glacial margins somewhere surrounding the Nordic Seas, and does not in itself give any further information about the properties and provenance of this ice. Provenance analysis of IRD is theoretically possible, for example through isotope analysis (e.g., White et al., 2016), but this requires feldspar IRD, which was not noted in significant amounts. Cathodoluminescence analysis of quartz IRD (Müller and Knies, 2013) may in the future be used to trace ice-rafting sources and transport pathways during the Pliocene.

\section{Results}

We present $\mathrm{U}_{37}^{K^{\prime}}$ alkenone SSTs from the Norwegian Sea ODP Hole 642B with an average temporal resolution of $5.6 \mathrm{kyr}$ (range: 0.5 to $58 \mathrm{kyr}$ ) from 5.321 to $3.141 \mathrm{Ma}$ (Fig. 2c). The average Pliocene SST was $13.2^{\circ} \mathrm{C}$, about $2^{\circ} \mathrm{C}$ above the Holocene average at a nearby site $\left(11.2^{\circ} \mathrm{C}\right)$ (Fig. 1; Calvo et al., 2002; Site MD95-2011; $\left.66^{\circ} 58^{\prime} \mathrm{N}, 7^{\circ} 38^{\prime} \mathrm{E}\right)$. The record documents the existence of large-amplitude changes in $\mathrm{U}_{37}^{K^{\prime}}$ alkenone SST on millennial to orbital timescales. Some of the highest SSTs were measured in the earliest Pliocene (5.3 to 5.0 Ma; 85.66 to $83.46 \mathrm{~m}$ b.s.f.), a time interval which was marked by a cooling trend from 17 to $15^{\circ} \mathrm{C}$. From 5.0 to $4.64 \mathrm{Ma}$ (83.46 to $77.81 \mathrm{~m}$ b.s.f.), the SST record varied between 11 and $15^{\circ} \mathrm{C}$ with a period of $\sim 10-30 \mathrm{kyr}$. Following this unstable period the SSTs remained relatively stable $\left(13.9\right.$ to $\left.15^{\circ} \mathrm{C}\right)$ between 4.64 and $4.45 \mathrm{Ma}$ (77.76 to $77.21 \mathrm{~m}$ b.s.f.). A pronounced cooling began from $15^{\circ} \mathrm{C}$ at $4.45 \mathrm{Ma}$ into an interval of sustained low Pliocene SSTs starting from 4.3 Ma and continuing to $4.0 \mathrm{Ma}$ (76.61 to $73.61 \mathrm{~m}$ b.s.f., which mostly lay below the Holocene average (down to a minimum of just 


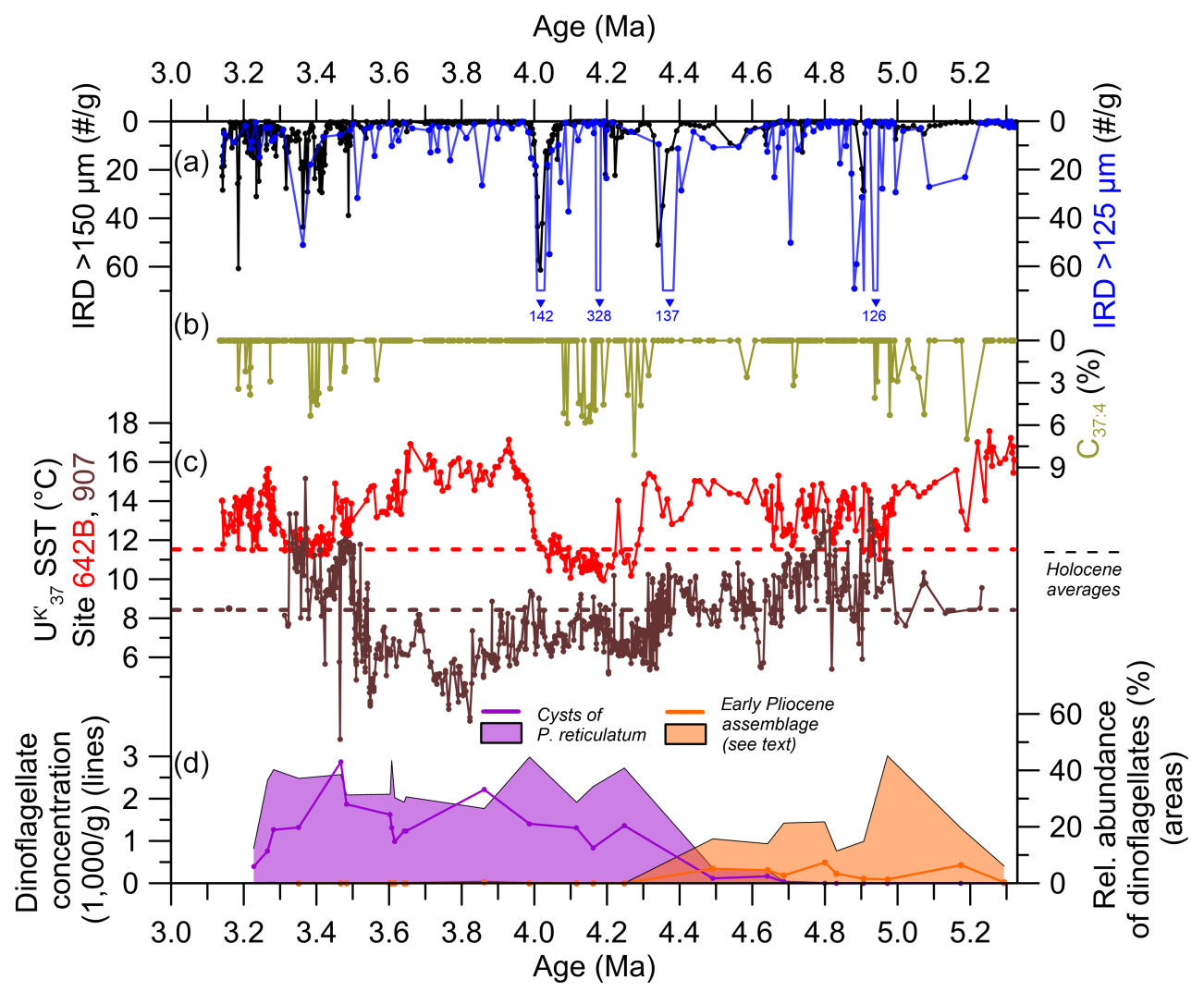

Figure 2. (a) IRD $>150 \mu \mathrm{m}$ (black line, this study) and $>125 \mu \mathrm{m}$ (blue line, Jansen et al., 1990). (b) \%C $37: 4$. (c) $\mathrm{U}_{37}^{K^{\prime}} \mathrm{SSTs}$ (Müller et al., 1998 calibration). New data from ODP Hole 642B in red, data from ODP Site 907 in brown (Herbert et al., 2016; age model revised by Clotten et al., unpublished data). Dashed lines indicate Holocene average SSTs for the Norwegian Sea (red: Calvo et al., 2002) at $11.6^{\circ} \mathrm{C}$, and for the new Iceland Sea site GS15-198-62 MC-A, at 8.5 ${ }^{\circ} \mathrm{C}$ (brown: this study). (d) concentrations and relative abundances of dinoflagellate cysts at ODP Hole 642B. Purple: cysts of Protoceratium reticulatum. Orange: grouping of the most abundant Early Pliocene extinct taxa, including Reticulatosphaera actinocoronata, Ataxiodinium sp. A, Batiacasphaera micropapillata complex, and Operculodinium tegillatum (De Schepper et al., 2015).

over $10^{\circ} \mathrm{C}, 1.2^{\circ} \mathrm{C}$ below the Holocene average). Significant warming, from $\sim 11$ to $\sim 17^{\circ} \mathrm{C}$, then occurred within $70 \mathrm{kyr}$ from $\sim 4.0$ to $3.93 \mathrm{Ma}$ (73.57 to $73.01 \mathrm{~m}$ b.s.f.). An extended period of warmth lasted from 3.93 until $3.65 \mathrm{Ma}$ (70.47 m b.s.f.), marked by SSTs between 15 and $17^{\circ} \mathrm{C}$. Ending this extended warm period, SSTs first cooled to around $13.5^{\circ} \mathrm{C}$ between 3.65 and $3.45 \mathrm{Ma}$ (70.41 to $68.92 \mathrm{~m}$ b.s.f.), succeeded by an even colder interval from 3.45 to $\sim 3.3 \mathrm{Ma}$ (68.90 to $68.42 \mathrm{~m}$ b.s.f.), during which mean SSTs remained close to $12^{\circ} \mathrm{C}$. From 3.3 Ma, a rapid SST increase from $\sim 12.4^{\circ} \mathrm{C}$ at $3.3 \mathrm{Ma}$ to $15.6^{\circ} \mathrm{C}$ at $3.26 \mathrm{Ma}(68.10 \mathrm{~m}$ b.s.f.) was recorded.

The percentage of tetra-unsaturated alkenone $\left(\% \mathrm{C}_{37: 4}\right.$, Fig. 2b) was generally very low, lying close to the detection limit $(<1 \%)$ for much of the Pliocene. Increases in $\% \mathrm{C}_{37: 4}$ maxima of 4 to $8 \%$ occurred during phases when SSTs were comparable to Holocene values, i.e., at $4.9 \mathrm{Ma}$, between 4.3 and 4.0 Ma, and between 3.6 and 3.3 Ma.

The IRD counted in Hole 642B consists mainly of quartz grains and metamorphic rock fragments. The new high-resolution record shown here compares well with the lower-resolution IRD record from the same site by Jansen and Sjøholm (1991). Pulses of IRD $>150 \mu \mathrm{m}$ (Fig. 2a) reach the Norwegian Sea around $4.9 \mathrm{Ma}\left(70\right.$ grains g $\left.^{-1}\right)$, $4.74 \mathrm{Ma}\left(25\right.$ grains $\left.^{-1}\right), 4.62 \mathrm{Ma}\left(19\right.$ grains $\left.^{-1}\right), 4.34 \mathrm{Ma}$ $\left(38\right.$ grains $\left.^{-1}\right), \quad 4.2 \mathrm{Ma} \quad\left(22\right.$ grains $\left.\mathrm{g}^{-1}\right), \quad$ and $4.0 \mathrm{Ma}$ $\left(100\right.$ grains $\left.\mathrm{g}^{-1}\right)$. After a largely IRD-free interval from 4.0 to $3.6 \mathrm{Ma}$, IRD influx increases in variability and amount

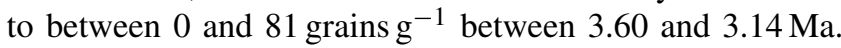
The IRD peaks reported here are at the same order of magnitude as IRD deposition at the Vøring Plateau during the last interglacial (Risebrobakken, unpublished data, not shown), and are hence not comparable to Pleistocene glacial deposition of IRD.

\section{Discussion}

The Pliocene Norwegian Sea was on average $2{ }^{\circ} \mathrm{C}$ warmer than the Holocene mean (Calvo et al., 2002); however, large and well-defined temperature transitions occurred at several 
times. These new SST data, supported by IRD and $\% \mathrm{C}_{37: 4}$ records, enable us to investigate the sea surface conditions of the Norwegian Sea at orbital (20 to $400 \mathrm{kyr}$ ) to tectonic (100 kyr to several Myr) timescales. There is no indication of stable warmth throughout the Pliocene at Hole 642B; rather, there are clear signs of several complex and extended cooling phases (e.g., long-term cooling trend between 5.3 and 4.3 Ma, and between 3.6 and $3.4 \mathrm{Ma}$ ) and relatively fast warming phases (e.g., at 4.0 and at 3.3 Ma). Here, we discuss the effects of tectonic and oceanographic changes on the surface conditions of the Norwegian Sea and consider the potential ramifications for the process of Northern Hemisphere Glaciation during the Pliocene. We discuss the evolution of the Pliocene climate between 5.32 and $3.14 \mathrm{Ma}$, noting which factors may have influenced the Norwegian Sea during defined time windows, following the local climate phases defined in Risebrobakken et al. (2016). Pliocene interactions between the relatively warm Norwegian Sea, sea ice, and terrestrial ice expansion may give clues to the general behavior of the high-latitude climate system during periods of increased global warmth.

$\mathrm{Up}$ to $3.5^{\circ} \mathrm{C} \mathrm{SST}$ change is seen within the Holocene at the study location (Fig. 1). Despite such rather large SST changes during the present interglacial, the amplitude of the large-scale SST changes recorded through the Pliocene is even larger. Furthermore, the Pliocene Hole 642B SSTs are overall warmer than those of the Holocene but are within the range of Holocene temperatures during the colder intervals, e.g., 4.3 to $4 \mathrm{Ma}$.

\subsection{Gradual Early Pliocene cooling of Norwegian Sea SSTs, 5.3 to $5.0 \mathrm{Ma}$}

Overall, SSTs in the Norwegian Sea cooled between 5.3 and 5.0 Ma. While the sample resolution is relatively low in this time interval, we note that the SST contrast between the Norwegian Sea (Hole 642B) and the Iceland Sea (Site 907; Herbert et al., 2016) was $2-3{ }^{\circ} \mathrm{C}$ above Holocene levels during the earliest Pliocene (Fig. 3b) (Herbert et al., 2016), indicating that the Nordic Seas were already zonally differentiated. The SST gradient between the North Atlantic and the Nordic Seas was significantly stronger than the modern $\mathrm{U}_{37}^{K^{\prime}}$ SST gradient (Fig. 4). Note that the age model for the Herbert et al. (2016) $\mathrm{U}_{37}^{K^{\prime}} \mathrm{SST}$ record was revised based on Jansen et al. (2000) (Clotten et al., unpublished data). Elevated $\% \mathrm{C}_{37: 4}$ coincide with the coldest recorded temperatures at Hole $642 \mathrm{~B}$ within the 5.3 to $5.0 \mathrm{Ma}$ interval, $12.5^{\circ} \mathrm{C}$ at $5.19 \mathrm{Ma}$, indicating that a short-term increase in cold water masses influenced the surface of the Norwegian Sea. There was no IRD associated with the cooling and no clear driver is evident (Fig. 2).

\subsection{Unstable sea surface conditions, 5.0 to $4.64 \mathrm{Ma}$}

Between 5.0 and 4.64 Ma, SSTs in the Norwegian Sea are highly variable, ranging from just below the Holocene average of $11.6^{\circ} \mathrm{C}$ up to $15^{\circ} \mathrm{C}$ (Fig. 2c). Periods of low SSTs are accompanied by increasing influx of IRD and sporadic increases in $\% \mathrm{C}_{37: 4}$, indicating increased influence of cooler and possibly less saline water masses towards Hole 642B. Corresponding variability is also seen in the planktic and benthic carbon isotopes, implying changes in ocean-atmosphere exchange and bottom water ventilation (Fig. 3c-f; Risebrobakken et al., 2016). Similarly, the interaction between low SSTs and increased IRD at the same site during the mid-Piacenzian warm period appears to be driven largely by decreasing obliquity (Bachem et al., 2016a). Although we were unable to detect orbital periodicities in our SST data, we note that between 5.0 and 4.64 Ma the high variability in SSTs also coincides with especially high variability of obliquity (Fig. 5e; Laskar et al., 2004). The variability in SST at Hole 642B could potentially be accounted for by highly variable obliquity forcing causing successive transitions between times of stronger and weaker seasonal insolation (Berger, 1988). During times of weaker seasonality, the summers may have been cool enough to allow for the sporadic expansion of glaciers and calving of icebergs reaching the Norwegian Sea. During the 5.0 to $4.64 \mathrm{Ma}$ time interval the SSTs at Site 907 (Herbert et al., 2016) are highly variable as well (Fig. 2c), and the temperature gradient between the Iceland Sea and the Norwegian Sea (Fig. 3b) was comparable to the Holocene average, relatively small compared to the earliest Pliocene. The SST gradient between the North Atlantic and the Nordic Seas was, however, equally strong as before throughout most of this interval (Fig. 4).

The IRD we register at Site 642B does not exceed an estimated 1 to $2 \%$ of the total sediment weight of a given sample, much lower than during Nordic Seas ice-rafting events of Late Pleistocene glacials when IRD contents reached 50 to $100 \%$ (Heinrich, 1988). The recorded number of grains per gram sediment are in fact comparable to the number of IRD grains recorded in the same area during the last interglacial (not shown). This means that any IRD influx was likely a matter of sporadic and minor ice rafting, more comparable to the present-day setting than to any large-scale collapses of ice sheets comparable to those of the Late Pleistocene (Marcott et al., 2011). It should also be noted that the presence of IRD is not specifically linked to the growth rate of ice sheets, but to the extent of their interaction with the ocean. Extended periods of ice growth away from the coast, i.e., without calving margins, would not be visible in the IRD record (Ruddiman et al., 1980).

As noted in Bachem et al. (2016a) for the later Pliocene, the source of IRD in the Norwegian Sea may have been Greenland rather than the more proximal Scandinavia. This contrasts with a Scandinavian IRD source in Hole 642B proposed by Jansen and Sjøholm (1991). Our rationale is that 


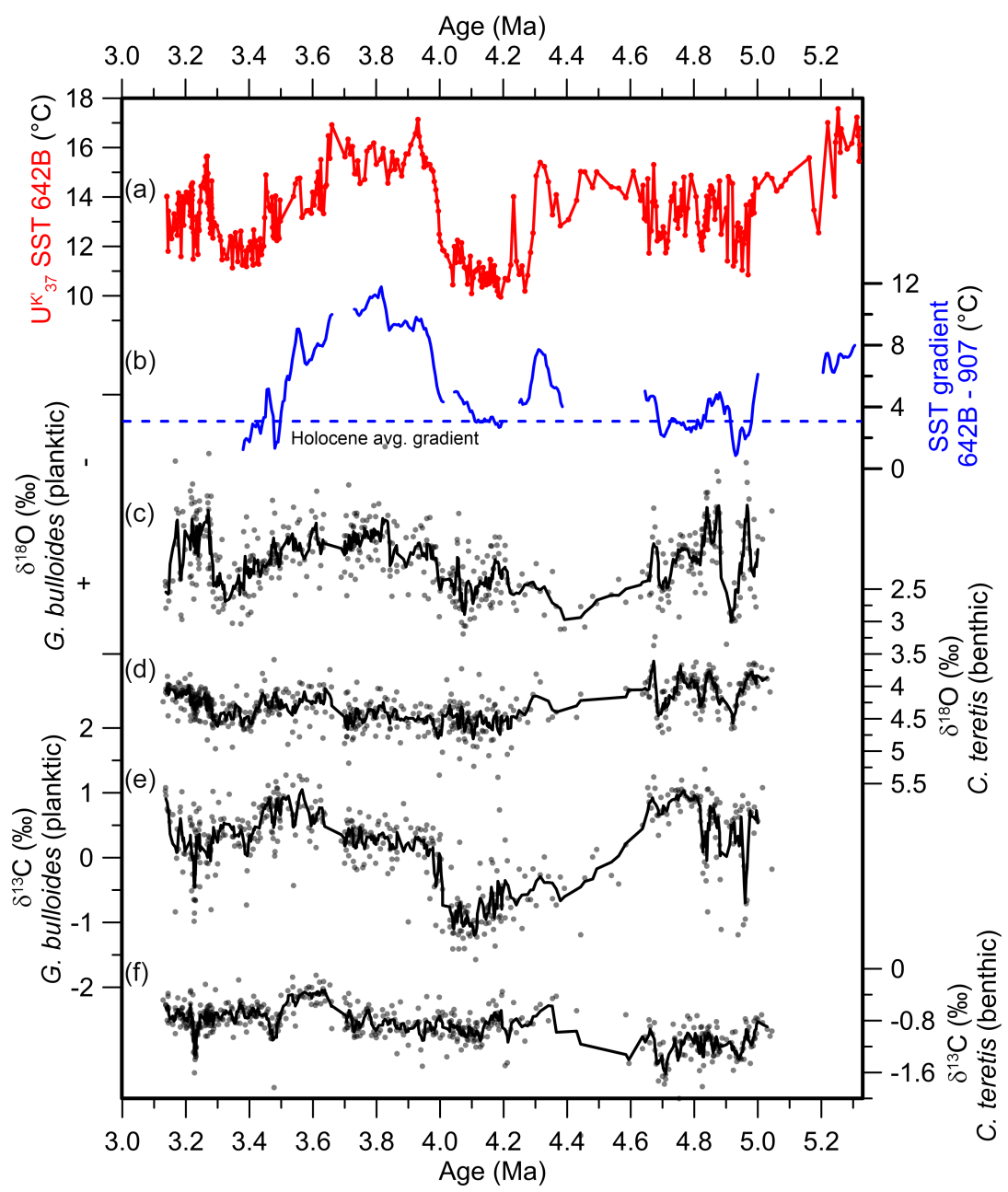

Figure 3. (a) $\mathrm{U}_{37}^{K^{\prime}}$ SSTs from Hole 642B. (b) SST gradient between Hole 642B and Site 907 (Herbert et al., 2016; age model revised by Clotten et al., unpublished data, interpolated to $5 \mathrm{kyr}$. Intervals where either record is above $10 \mathrm{kyr}$ resolution are not shown. The Holocene average gradient between the respective neighboring sites MD95-2011 and GS15-198-62 MC-A is marked by the dashed blue line. (c) Planktic $\delta^{18} \mathrm{O}(\mathrm{G}$. bulloides). Scale not shown due to documented diagenetic impacts on absolute values (Risebrobakken et al., 2016). (d) Benthic $\delta^{18} \mathrm{O}\left(C\right.$. teretis). (e) Planktic $\delta^{13} \mathrm{C}\left(G\right.$. bulloides). (f) Benthic $\delta^{13} \mathrm{C}(C$. teretis). All data from ODP Hole 642B. (c-f) From Risebrobakken et al. (2016). Grey dots represent raw isotope data; thick black lines indicate the five-point running average of isotope data.

the SSTs at Hole 642B, even though they were unstable, remained mostly above the Holocene average across the 5.0 to 4.64 Ma time interval. As Born et al. (2010) noted for the last interglacial, Scandinavian surface air temperatures had to be $3{ }^{\circ} \mathrm{C}$ cooler than the Holocene average to trigger glacial inception on Scandinavia. With ocean temperatures being up to $3{ }^{\circ} \mathrm{C}$ warmer than the Holocene, it is not likely that the atmospheric temperatures over Scandinavia were colder than today, and therefore calving glaciers probably did not occur at the coast of Norway. Within the interval from 5.0 to $4.65 \mathrm{Ma}$, the coldest Hole 642B SSTs are recorded just prior to $4.9 \mathrm{Ma}\left(10.86^{\circ} \mathrm{C}\right)$ (Fig. 2c), corresponding to a glaciation event with possible global extent that took place around 4.9 to $4.8 \mathrm{Ma}$ (Lisiecki and Raymo, 2005). This event at $4.9 \mathrm{Ma}$ is also marked by enhanced IRD input (Fig. 2a), and cool- ing throughout the water column at Hole $642 \mathrm{~B}$ as indicated by $\delta^{18} \mathrm{O}$ data (Fig. 3c, d; Risebrobakken et al., 2016). The gradual SST cooling from 5.3 to 5.0 Ma culminates with the 4.9 Ma cold event (Fig. 2), which is also indicated by dinoflagellate assemblage changes (De Schepper et al., 2015). The gradual cooling may therefore have influenced the regional climate and ice growth leading up to the $4.9 \mathrm{Ma}$ global glaciation event.

\subsection{From stable warm $\left(15^{\circ} \mathrm{C}\right)$ to stable cold $\left(10.5^{\circ} \mathrm{C}\right)$ Norwegian Sea SSTs, 4.64 to $4.0 \mathrm{Ma}$}

Following rather stable and warm surface conditions $\left(\sim 15^{\circ} \mathrm{C}\right)$ from 4.64 to $4.45 \mathrm{Ma}$, an initial cooling phase is noted at $4.45 \mathrm{Ma}$, from $15^{\circ} \mathrm{C}$ to $12.8^{\circ} \mathrm{C}$, and a subsequent extended cold period begins at $4.3 \mathrm{Ma}$ (Fig. 2c). These cold 


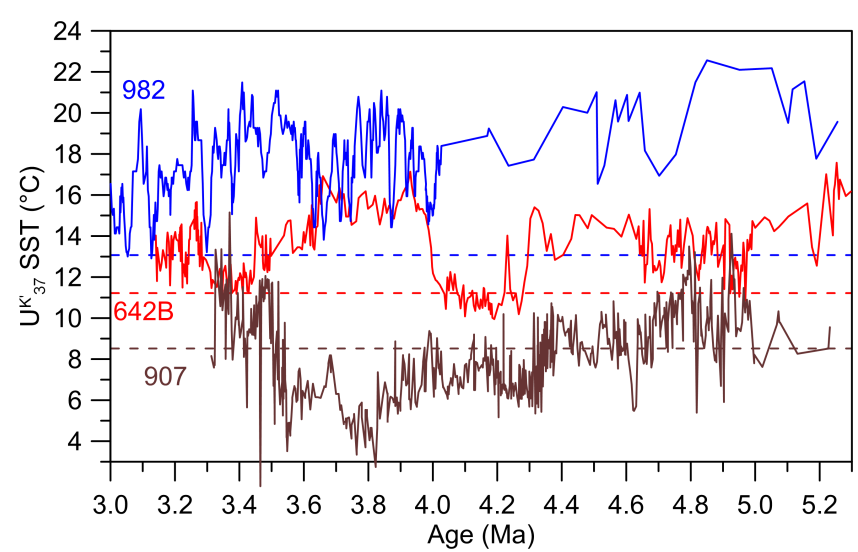

Figure 4. Sea surface temperature records from ODP Site 982 (blue; 4 to $3 \mathrm{Ma}$ : Lawrence et al., 2009; 5.3 to $4 \mathrm{Ma}$ : Herbert et al., 2016), compared to SSTs from ODP Hole 642B (red, this study) and ODP Site 907 (brown, Herbert et al., 2016; age model revised by Clotten et al., unpublished data). Comparable averages are indicated by respective dashed lines (982: core-top data, Lawrence et al., 2009; 642B: Holocene average, Calvo et al., 2002; 907: Holocene average, this study).

intervals coincide with an interval of especially weak amplitude in obliquity forcing between 4.4 and 4.0 Ma (Fig. 5e). The single high amplitude obliquity cycle that occurred in this time interval, at $4.2 \mathrm{Ma}$, is associated with a peak of SST. Overall, a relationship between a generally reduced seasonality (low obliquity) and low SSTs in the Norwegian Sea characterizes the average state for the 4.3 to $4.0 \mathrm{Ma}$ interval. Sporadic peaks of $\% \mathrm{C}_{37: 4}$, albeit small, are associated with the coldest SSTs between 4.3 and $4.0 \mathrm{Ma}$, suggesting an enhanced influence of cool water masses in the Norwegian Sea. Peaks of IRD appear in association with the cool phase around $4.38 \mathrm{Ma}$, as well as during the 4.3 to $4.0 \mathrm{Ma}$ cold interval (Fig. 2a, c). No IRD peak corresponds to the rapid cooling at $4.3 \mathrm{Ma}$, but the strongest IRD peak of the record begins at the end of the 4.3 to $4.0 \mathrm{Ma}$ cool period, just before the rapid warming transition at $4.0 \mathrm{Ma}$. The combined reduced SSTs, increased $\% \mathrm{C}_{37: 4}$, and IRD support previously published records which indicated that interval between 4.4 and 4.0 Ma was relatively cold in the Norwegian Sea, with a reduced planktic-benthic $\delta^{13} \mathrm{C}$ gradient suggesting a water mass structure not too dissimilar from that of the Holocene (Fig. 3e, f; Risebrobakken et al., 2016). The increase in IRD at Hole 642B from 4.05 Ma precedes the major increase in SSTs at $4.0 \mathrm{Ma}$ (Fig. 2); therefore, increased calving did not occur as a response to this large-scale warming. The phase of weak obliquity variability from 4.3 to 4.05 Ma may have enabled the build-up of small-scale glaciation around the Nordic Seas large enough to shed icebergs into the ocean. The minor warming and increase in IRD at $4.05 \mathrm{Ma}$ coincides with an increased obliquity (Fig. 5), suggesting a potential role for increased seasonality in causing local warm- ing and/or the retreat of small-scale marine-based glaciers existing in the Nordic Seas realm.

The change in SSTs from the stable warm conditions between 4.64 and $4.45 \mathrm{Ma}$ to the stable cold conditions between 4.3 and $4.0 \mathrm{Ma}$ can also be seen in relation to the onset of northward through-flow in the Bering Strait (Marincovich and Gladenkov, 1999), the establishment of the EGC and the onset of modern circulation in the Nordic Seas, the latter suggested to have occurred around 4.5 Ma (De Schepper et al., 2015). The modern oceanographic pattern of the Nordic Seas is characterized by a strong zonal gradient of SST and salinity between the cold and fresh EGC to the west and the warm and saline NwAC to the east (Fig. 1). De Schepper et al. (2015) identified major changes in the dinoflagellate cyst assemblages around 4.5 Ma in both the Iceland and Norwegian Sea, including an assemblage turnover, decrease in cyst concentrations and broadly contemporaneous extinctions of four species. Following the disappearance of these taxa in Hole 642B (Fig. 2d) around 4.5 Ma, and a decrease in heterotrophic taxa, the cosmopolitan cysts of dinoflagellate species Protoceratium reticulatum increase in abundance and concentration. This is interpreted as a significant shift in the water mass characteristics of the Norwegian Sea likely due to increasing influence of warm North Atlantic water on the Norwegian Sea relative to the Iceland Sea, which is more influenced by the establishment of the EGC. However, when comparing the $\mathrm{U}_{37}^{K^{\prime}}$ SST records from Hole 642B and Site 907 (Herbert et al., 2016; De Schepper et al., 2015), the zonal SST gradient between the sites varied between 2 and $6^{\circ} \mathrm{C}$ during the period 5.3 to $4.0 \mathrm{Ma}$ (Fig. $3 \mathrm{~b}$ ). This suggests an earlier establishment of the modern zonal differentiation of the Nordic Seas compared to the changes in dinoflagellate assemblages that took place at 4.5 Ma (Fig. 2d; De Schepper et al., 2015). The coupling remained intact through the cooling from 4.5 to $4.0 \mathrm{Ma}$. The $\mathrm{U}_{37}^{K^{\prime}} \mathrm{SST}$ trends at ODP Hole 642B and Site 907 are roughly comparable in timing and amplitude, and the gradient between both sites is weakest (ca. 3 to $4{ }^{\circ} \mathrm{C}$; Fig. 3b) when the Norwegian Sea was at its coolest between 4.3 and 4.0 Ma. Hence, these new data suggest that while cooling at ODP Site 907 may originate from the establishment of the EGC at ca. $4.5 \mathrm{Ma}$, no warming occurs in the NwAC until 4.0 Ma. This lack of warming, despite an increased Atlantic water influence from around 4.2 Ma onwards as suggested by the increase in cysts of $P$. reticulatum (De Schepper et al., 2015), would imply that northward heat transport by the North Atlantic Current was still relatively low.

The existence of a modern-like circulation, despite the potentially weakened heat transport, is supported by overflow at the Denmark Strait (Bohrmann et al., 1990) and enhanced ventilation of intermediate depths in the Nordic Seas between 4.5 and 4.4 Ma (Risebrobakken et al., 2016). Various studies have suggested that a shallow opening of the Central American Seaway (CAS) before the Late Pliocene (Bartoli et al., 2005; Haug and Tiedemann, 1998; Kameo and Sato, 2000; 


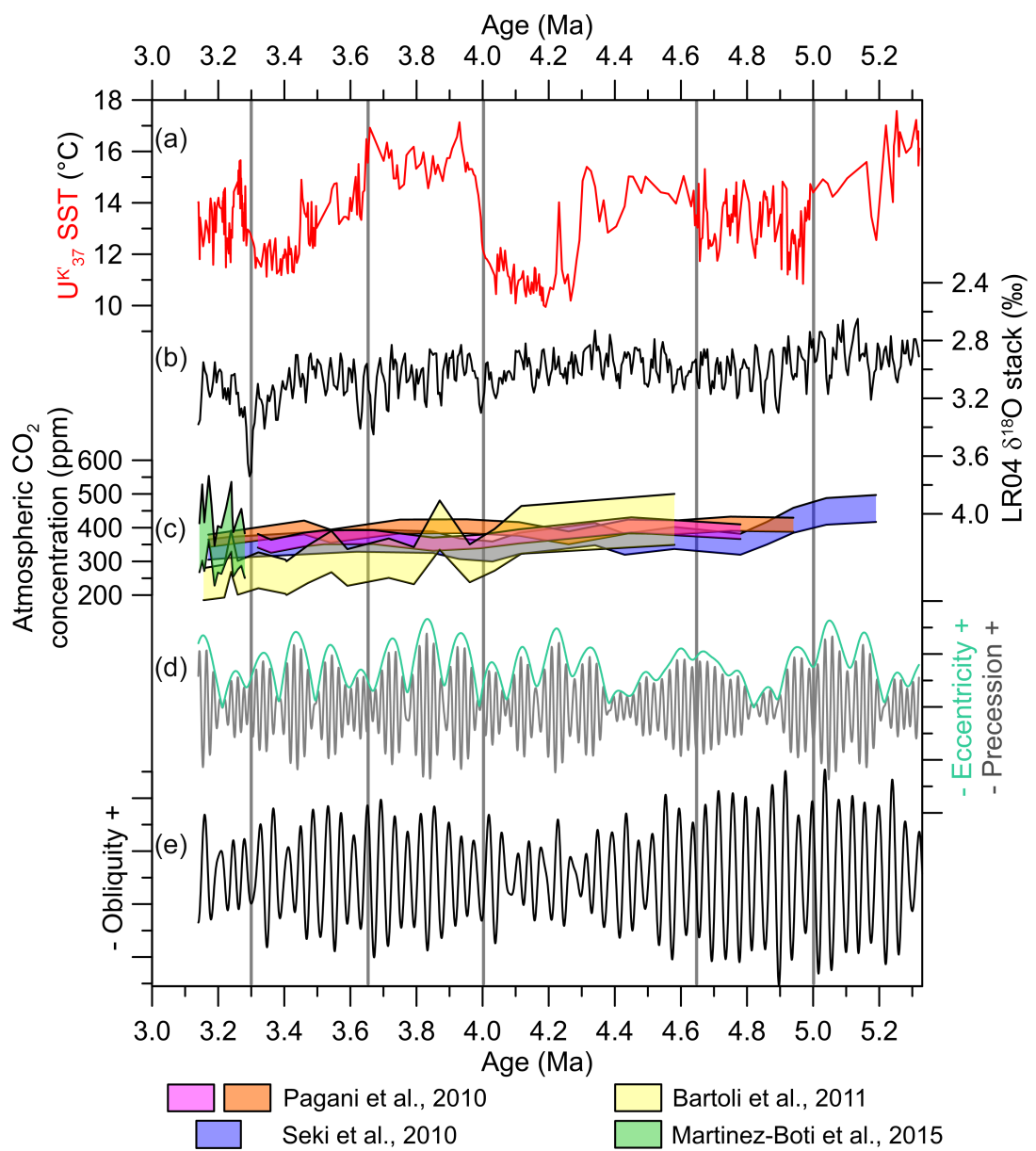

Figure 5. (a) SSTs from ODP Hole 642B; (b) benthic $\delta^{18} \mathrm{O}$ isotope stack LR04 (Lisiecki and Raymo, 2005); (c) examples of Pliocene atmospheric $\mathrm{CO}_{2}$ concentration proxy data; (d) precession and eccentricity envelope; (e) obliquity (panels $\mathbf{d}$ and $\mathbf{e}$ from Laskar et al., 2004). Local climate transitions at ODP Hole 642B discussed here are marked by vertical lines.

Osborne et al., 2014; Steph et al., 2010) has in part been responsible for a weaker than modern northward heat transport at this time. A persistent shallow opening of the CAS is potentially responsible for reduced northward heat transport, as indicated by model comparisons between an open and a closed CAS (e.g., Maier-Reimer et al., 1990; Zhang et al., 2012). Alternatively, a reduction of the water depth over the GSR at approximately this time (Poore et al., 2006) could have resulted in lower SSTs in the Nordic Seas, in contrast to overall higher SSTs being the response to increased water depth over the GSR (Robinson et al., 2011; Hill, 2015). However, this may be inconsistent with the change towards more $P$. reticulatum in the dinoflagellate cyst assemblage, which is interpreted to show a stronger North Atlantic water mass influence on the Norwegian Sea (De Schepper et al., 2015).

\subsection{Rapid warming followed by extended interval of high SSTs, 3.95 to $3.65 \mathrm{Ma}$}

From 4.0 to $3.95 \mathrm{Ma}$, ODP Hole 642B records a dramatic increase in SSTs from around 10 to $17^{\circ} \mathrm{C}$ over ca. $70 \mathrm{kyr}$ $\left(0.14{ }^{\circ} \mathrm{C} \mathrm{kyr}^{-1}\right)$, making it the longest and largest warming episode of the record. The warming was followed by a relatively stable warm period from 3.95 to $3.65 \mathrm{Ma}\left(15\right.$ to $\left.17^{\circ} \mathrm{C}\right)$. As high SSTs developed at Hole 642B the SSTs at ODP Site 907 decreased and remained at a Pliocene low until 3.55 Ma (Herbert et al., 2016; De Schepper et al., 2015). Hence, the zonal gradient in the Nordic Seas intensified during the 4.0 to $3.95 \mathrm{Ma}$ transition, when the SST contrast between the Iceland Sea and the Norwegian Sea reached a sustained maximum of $\sim 10^{\circ} \mathrm{C}$, significantly larger than the Holocene difference of $\sim 3^{\circ} \mathrm{C}$ (Fig. 3b). The high SSTs in the Norwegian Sea and the strong zonal temperature gradient within the Nordic Seas suggests that the surface circulation of the Nordic Seas was more vigorous during this time period. Strong inflow of warm Atlantic water is also indi- 
cated by enriched planktic $\delta^{13} \mathrm{C}$ at Hole 642B, which is likely caused by enhanced ocean-atmosphere gas exchange in the upper water (Fig. 3e; Risebrobakken et al., 2016).

The warming of the Norwegian Sea at $4.0 \mathrm{Ma}$ coincides with several tectonic shifts that could affect the climate development of the Nordic Seas region. A threshold in the closure of the CAS has been suggested to take place at this time (Karas et al., 2017; Steph et al., 2010), and uplift of Greenland and northern Scandinavia took place (Knies et al., 2014a). Enhanced North Atlantic Deep Water (NADW) production and a more vigorous AMOC have been suggested by Steph et al. (2010) towards 4.0 Ma based on benthic $\delta^{13} \mathrm{C}$ in the low-latitude Atlantic. However, consistently low benthic $\delta^{13} \mathrm{C}$ in the Norwegian Sea (Fig. 3f; Risebrobakken et al., 2016) indicates that bottom water ventilation at the Vøring Plateau did not increase. This is in line with other studies, where no response of benthic $\delta^{13} \mathrm{C}$ is seen at other Atlantic sites during this part of the Pliocene (Bell et al., 2015; Zhang et al., 2013), indicating that the changes may have been limited to specific water masses in the Caribbean region, and that increased heat transport to the Norwegian Sea was not linked to an intensification of the AMOC. If it is the case that no large-scale AMOC strengthening took place, regional changes in water mass transport may instead be responsible for the warming of the Norwegian Sea around 4.0 Ma. While the timing of ridge depth evolution is not very well constrained (Wright and Miller, 1996; Poore et al., 2006), it is possible that a threshold shift in GSR depth took place around $4.0 \mathrm{Ma}$, allowing for a more vigorous inflow of warm North Atlantic water into the Norwegian Sea from this point forward. The impact of the GSR on Nordic Seas climate has been indicated by model experiments, which suggest that a deepening would lead to a slight warming of the Norwegian Sea and a cooling around Iceland (Hill, 2015). More detailed studies of the GSR system may shed more light on its effect on Nordic Seas climate development.

There are additional indicators for regional climate rearrangements in high northern latitudes at this time. Tectonic uplift took place around both Greenland and Scandinavia at 4.0 Ma (Japsen et al., 2006; Knies et al., 2014a), and may have been important for the enhanced regional glaciation on Greenland that took place at this time (Japsen et al., 2006; De Schepper et al., 2014; Solgaard et al., 2013). The period of consistently warm SSTs that occurred in the Norwegian Sea and North Atlantic between 4.0 and 3.65 Ma may have triggered increased evaporation and hence precipitation, which can increase the Arctic freshwater supply and facilitate sea ice formation in the Arctic (Driscoll and Haug, 1998) if SSTs here are low enough. The Arctic sea ice cover extended towards the Fram Strait (ODP Site 910C) for the first time during the Pliocene at 4.0 Ma (Knies et al., 2014b), and the associated increased sea ice export would have further cooled the EGC and in consequence the eastern Nordic Seas (Herbert et al., 2016). In turn, a stronger zonal gradient in the Nordic Seas would have been enforced and shielded the growing
Greenland ice cover from the warm NwAC (Bohrmann et al., 1990; Japsen et al., 2006; De Schepper et al., 2015; Solgaard et al., 2013). Uplift and increased precipitation may have enabled lateral ice sheet growth in the interior of Greenland from 4.0 Ma onward, which could take place without producing a notable IRD record (Ruddiman et al., 1980; Solgaard et al., 2013). Hence, the uplift of Greenland, in combination with enhanced supply of freshwater to the Arctic due to increased moisture transport and runoff, likely supported the cooling and the first appearance of winter sea ice in the Fram Strait at 4.0 Ma, as suggested by Knies et al. (2014b). The warming documented in the Norwegian Sea at $4.0 \mathrm{Ma}$ (Hole 642B), in combination with the corresponding cooling in the northern Nordic Seas (Hole 910C; Knies et al., 2014b) and the Iceland Sea (Site 907; Herbert et al., 2016; De Schepper et al., 2015), indicates a strengthening of both the zonal and the meridional temperature gradient in the Nordic Seas. Risebrobakken et al. (2016) noted that the increased freshwater and sea ice flux in the EGC may have supported the warming in the NwAC by reinforcing the counter-flow of warm Atlantic water in the Norwegian Sea. A warm North Atlantic from 4.0 to $3.65 \mathrm{Ma}$ is supported by $\mathrm{U}_{37}^{K^{\prime}} \mathrm{SST}$ data from ODP Site 982 (Fig. 4; Lawrence et al., 2009), which lies within the pathway of modern-day North Atlantic inflow into the Nordic Seas (Fig. 1). Hence, while the meridional temperature gradient between the Vøring Plateau (Hole 642B) and the Fram Strait (Hole 910C) was increased, the SST gradient between the North Atlantic (Site 982) and the Vøring Plateau was reduced, compared to the preceding interval.

\subsection{Gradual cooling, 3.65 to $3.3 \mathrm{Ma}$}

Sea surface temperatures decrease from an average of $16^{\circ} \mathrm{C}$ between 4.0 and $3.65 \mathrm{Ma}$ to an average of $14^{\circ} \mathrm{C}$ between 3.65 and $3.45 \mathrm{Ma}$, before reaching a cold average of $11.5^{\circ} \mathrm{C}$ between 3.4 and $3.3 \mathrm{Ma}$ (Fig. 2c). Instances of gradually increased $\% \mathrm{C}_{37: 4}$ accompany the SST decrease between 3.55 and 3.35 Ma (Fig. 2b). The influx of IRD increases around 3.55 Ma, after the beginning of the cooling trend. There does not appear to be a link between the cooling trend of the sea surface conditions and orbital forcing in this time period. Obliquity variability was relatively strong and remained so until well after the cool surface conditions were established (Fig. 5a, e).

The surface cooling in the Norwegian Sea from 3.65 Ma may reflect the global cooling that has been proposed to begin around 3.6 Ma by Mudelsee and Raymo (2005), which they link to a gradual overall increase in NHG. The observed cooling also corresponds to and supports a potential surface water density increase in the Norwegian Sea (Hole 642B), which was interpreted as potentially driven by regional cooling (Fig. 3e) (Panitz et al., 2016; Risebrobakken et al., 2016). The gradual increase in the magnitude and regularity of IRD concentration supports the idea of advancing glaciation around the Nordic Seas from 3.6 Ma. A somewhat enhanced 
overturning circulation, improving the ventilation of the intermediate water depths of the Nordic Seas at this time, is indicated (Risebrobakken et al., 2016), and the warm SSTs at the North Atlantic ODP Site 982 may suggest an enhanced northward heat transport (Fig. 4; Lawrence et al., 2009). If the northward heat transport was strong during the 3.65 to 3.3 Ma time period, the cooling we note in Norwegian Sea SSTs took place at a time when increased SSTs could be expected due to a potentially increased northward heat transport trough the NAC, a seemingly contradictory scenario.

The decrease in SSTs could rather be explained by a decreased impact of the NAC on the NwAC. The SST gradient between ODP Hole 642B and ODP Site 907 (Fig. 3b) appears to be greatly reduced but variable $\left(0\right.$ to $\left.3{ }^{\circ} \mathrm{C}\right)$ during the particularly cool phase at Hole 642B from 3.45 to $3.35 \mathrm{Ma}$. The high variability and increased SSTs at Site 907 (Herbert et al., 2016) may be indicative of a weakening of the circulation in the Nordic Seas, or a shift in the overall circulation pattern, with a largely weakened or reduced EGC and increased heat transport towards the Iceland Sea. Schreck et al. (2013) noted (nearly) monospecific dinoflagellate assemblages during the 3.45 to $3.35 \mathrm{Ma}$ interval at ODP Site 907. A higher-resolution investigation of ODP Site 907 identified high concentrations of an unspecified Spiniferites species between 3.7 and 3.3 Ma (De Schepper, unpublished data). Fronval and Jansen (1996) report the only occurrence of foraminifera at Site 907 near 3.3 Ma, deviating from a generally carbonate barren record during the Late Pliocene and supporting the notion that conditions in the Iceland Sea were unusual at this time. A possible interpretation is that the influence of the Atlantic domain in the Nordic Seas was spread out laterally during this the 3.65 to 3.3 Ma period, weakening the overall influence at the Vøring Plateau but strengthening it in the Iceland Sea. It thus appears that regional water mass redistributions were more important for the sea surface development than a potential global cooling proposed by Mudelsee and Raymo (2005).

\subsection{The mid-Piacenzian warm period, 3.3 to $3.14 \mathrm{Ma}$}

The records of sea surface conditions presented here, as well as other previously reported records from ODP Hole 642B (Jansen and Sjøholm, 1991; Risebrobakken et al., 2016), find no indication of the global cooling event that has been noted to take place during Marine Isotope Stage M2 (MIS M2, 3.312 to $3.264 \mathrm{Ma}$; Lisiecki and Raymo, 2005). This lack of recorded cooling may indicate the presence of a short-lived hiatus in the sediment sequence at ODP Hole 642B, or that the event had no particularly pronounced cooling impact on the Norwegian Sea. Cooling during MIS M2 had been noted in the North Atlantic by Lawrence et al., 2009) (Fig. 4) and by De Schepper et al. $(2009,2013)$ and an increase in IRD has been reported from the Iceland Sea (Jansen et al., 2000). In the Norwegian Sea we note a strong warming in the later part of MIS M2, in line with the corresponding decrease in global ice volume (Lisiecki and Raymo, 2005). The Norwe- gian Sea warming has also been indicated by pollen records stemming from the northern Norwegian landmass, which indicate vegetation adapted to warmer-than-present climate (Panitz et al., 2016).

During the period following 3.264 Ma the Norwegian Sea SSTs were 2 to $3{ }^{\circ} \mathrm{C}$ warmer than during the Holocene (Fig. 2c) (Bachem et al., 2016a). Global temperature was also 2 to $3{ }^{\circ} \mathrm{C}$ warmer than present (e.g., Dowsett et al., 2016). Even though warm SSTs prevailed in the Norwegian Sea, variable conditions existed, following changes in radiative forcing and a vigorous subpolar gyre, as indicated by the similar pattern of cooling seen in Hole 642B and Site 982 (Bachem et al., 2016a; Lawrence et al., 2009). The Iceland Sea record of ODP Site 907 (Herbert et al., 2016) does not have the necessary resolution for a direct comparison to the Norwegian Sea and North Atlantic records, although the SSTs at Site 907 appear to have been highly variable (Fig. 2c). The zonal gradient between the Iceland Sea and the Norwegian Sea was similar to the Holocene average during much of the 3.3 to 3.14 Ma period. This suggests a circulation that was similar to that of the Holocene in the Nordic Seas between 3.30 and $3.14 \mathrm{Ma}$, but that northward heat transport was likely stronger than between 3.45 and $3.35 \mathrm{Ma}$, but weaker than between 3.95 and $3.65 \mathrm{Ma}$.

\section{Conclusions}

Several climate transitions took place in the Norwegian Sea throughout the Pliocene, indicating a variable climate instead of a steady long-term cooling trend. The average temperature of the Pliocene was $13.6^{\circ} \mathrm{C}, 2^{\circ} \mathrm{C}$ warmer than the regional Holocene average of $11.6^{\circ} \mathrm{C}$, yet temperature changes of up to $7^{\circ} \mathrm{C}$ did take place. The Early Pliocene sea surface conditions between 5.32 and 4.64 Ma were highly variable (swings between 11 and $15^{\circ} \mathrm{C}$ over a few $10 \mathrm{kyr}$ ), which appears to be partially related to high-amplitude orbital variability. A zonal SST gradient comparable of that of the Holocene $\left({ }^{\circ} \mathrm{C}\right)$ already existed in the Nordic Seas during this time. The entire Nordic Seas cooled between 4.5 and 4.3 Ma, which is interpreted to reflect a strengthening of the EGC and the eastward extension of the Arctic Front, as well as reduced seasonality due to reduced amplitude of obliquity forcing. Low temperatures near or below the Holocene average persisted in the Norwegian Sea until 4.0 Ma. During the cool period from 4.3 to 4.0 Ma the zonal gradient in the Nordic Seas was at $\sim 4{ }^{\circ} \mathrm{C}$, near its Holocene level. A distinct warming took place between 4.0 and $3.95 \mathrm{Ma}$, from 10 to $17^{\circ} \mathrm{C}\left(0.14^{\circ} \mathrm{C} \mathrm{kyr}^{-1}\right)$, likely linked to increased northward heat transport due to enhanced overturning, and a return towards stronger seasonality. A steep increase in the zonal gradient of the Nordic Seas, leading to a contrast of up to $10^{\circ} \mathrm{C}$ (more than 3 times the Holocene gradient), set in after 4.0 Ma and lasted throughout the Norwegian Sea warm phase until 3.6 Ma, indicating a strongly increased northward heat transport. Norwe- 
gian Sea SSTs show cooling after $3.65 \mathrm{Ma}$, coinciding with global cooling and increasingly widespread glacial expansion. The Norwegian Sea cooled and the zonal gradient of the Nordic Seas decreased sharply, potentially due to a wider spread of Atlantic water. During the 3.264 to 3.14 Ma period, the Nordic Seas SSTs were higher than modern, although not as high as during the 3.95 to 3.65 Ma period. While glaciation around the Nordic Seas is indicated by the existence of IRD throughout the record (5.33 to $3.14 \mathrm{Ma}$ ), the relatively warm SSTs as well as the sporadic and small-scale nature of the IRD influx imply that Scandinavia did not experience significant glaciation during this interval. The Nordic Seas underwent several large-scale transformations of its surface conditions and zonal gradients during the Pliocene, at least in part caused by regional tectonic shifts, which shows that this region was highly dynamic and sensitive to changes in heat transport even before Northern Hemisphere ice sheets expanded. The documented oceanographic changes in the Nordic Seas were likely important for the growth of smallscale Pliocene glaciers and the enhanced glacial expansion at high northern latitudes since 3.65 Ma through their influence on the Arctic fresh water regime.

Data availability. The new data presented here are available on the PANGAEA online data repository at https://doi.org/10.1594/PANGAEA.865217 (Bachem et al., 2016b).

Competing interests. The authors declare that they have no conflict of interest.

Acknowledgements. We thank the Norwegian Research Council for funding project no. 221712, "Ocean Controls on high-latitude climate sensitivity - a Pliocene case study" (OCCP). Erin L. McClymont received additional funding through from the Philip Leverhulme Prize. Stijn De Schepper acknowledges funding from the Norwegian Research Council (project no. 229819). We gratefully acknowledge the invaluable work of the Integrated Ocean Drilling Program and its legacy programs in acquiring the deep-sea sediments which were used in this study. We thank reviewers Clara Bolton and Yige Zhang for constructive comments. We also thank Juliane Müller, Amanda Hayton, and Martin West for technical assistance and advice in the laboratory.

Edited by: Luc Beaufort

Reviewed by: Clara Bolton and Yige Zhang

\section{References}

Andruleit, H. A.: Coccolithophore fluxes in the NorwegianGreenland Sea: Seasonality and assemblage alterations, Mar. Micropaleontol., 31, 45-64, https://doi.org/10.1016/S03778398(96)00055-2, 1997.
Bachem, P. E., Risebrobakken, B., and McClymont, E. L.: Sea surface temperature variability in the Norwegian Sea during the late Pliocene linked to subpolar gyre strength and radiative forcing, Earth Planet. Sc. Lett., 446, 113-122, https://doi.org/10.1016/j.eps1.2016.04.024, 2016a.

Bachem, P. E., Risebrobakken, B., De Schepper, S., and McClymont, E. L.: Ice rafted debris, tetra-unsaturated alkenone and reconstructed sea surface temperature in sediment of ODP Hole 104-642B, PANGAEA, https://doi.org/10.1594/PANGAEA.865217, 2016 b.

Bartoli, G., Sarnthein, M., Weinelt, M., Erlenkeuser, H., GarbeSchönberg, D., and Lea, D. W.: Final closure of Panama and the onset of northern hemisphere glaciation, Earth Planet. Sc. Lett., 237, 33-44, https://doi.org/10.1016/j.eps1.2005.06.020, 2005.

Bartoli, G., Hönisch, B., and Zeebe, R. E.: Atmospheric $\mathrm{CO}_{2}$ decline during the Pliocene intensification of Northern Hemisphere glaciations, Paleoceanography, 26, PA4213, https://doi.org/10.1029/2010PA002055, 2011.

Baumann, K.-H., Andruleit, H. A., and Samtleben, C.: Coccolithophores in the Nordic Seas: Comparison of living communities with surface sediment assemblages, Deep-Sea Res. Pt. II, 47, 1743-1772, https://doi.org/10.1016/S0967-0645(00)000059, 2000.

Bell, D. B., Jung, S. J. A., Kroon, D., Hodell, D. A., Lourens, L. J., and Raymo, M. E.: Atlantic Deep-water Response to the Early Pliocene Shoaling of the Central American Seaway, Sci. Rep., 5, 12252, https://doi.org/10.1038/srep12252, 2015.

Bendle, J. A. P., Rosell-Melé, A., and Ziveri, P.: Variability of unusual distributions of alkenones in the surface waters of the Nordic seas, Paleoceanography, 20, PA2001, https://doi.org/10.1029/2004PA001025, 2005.

Berger, A. L.: Milankovitch theory and climate, Rev. Geophys., 26, 624-657, https://doi.org/10.1029/RG026i004p00624, 1988.

Bleil, U.: Magnetostratigraphy of Neogene and Quaternary Sediment Series from the Norwegian Sea: Ocean Drilling Program, Leg 104, Proc. Ocean Drill. Program, Sci. Results, 104, 829-901, https://doi.org/10.2973/odp.proc.sr.104.1989, 1989.

Blindheim, J. and Østerhus, S.: The Nordic Seas, Main Oceanographic Features, in: The Nordic Seas: An Integrated Perspective, AGU, Washington, D.C., USA, 11-37, 2005.

Böhm, E., Lippold, J., Gutjahr, M., Frank, M., Blaser, P., Antz, B., Fohlmeister, J., Frank, N., Andersen, M. B., and Deininger, M.: Strong and deep Atlantic meridional overturning circulation during the last glacial cycle, Nature, 517, 73-76, https://doi.org/10.1038/nature14059, 2015.

Bohrmann, G., Henrich, R., and Thiede, J.: Miocene to Quaternary paleoceanography in the northern North Atlantic: Variability in carbonate and biogenic opal accumulation, in: Geological history of the polar oceans: Arctic versus Antarctic, Kluwer Academic Publishers, Dordrecht, the Netherlands, 647-675, 1990.

Born, A., Kageyama, M., and Nisancioglu, K. H.: Warm Nordic Seas delayed glacial inception in Scandinavia, Clim. Past, 6, 817-826, https://doi.org/10.5194/cp-6-817-2010, 2010.

Bradtmiller, L. I., McManus, J. F., and Robinson, L. F.: 231Pa/230Th evidence for a weakened but persistent Atlantic meridional overturning circulation during Heinrich Stadial 1, Nat. Commun., 5, 5817, https://doi.org/10.1038/ncomms6817, 2014. 
Calvo, E., Grimalt, J. O., and Jansen, E.: High resolution UK37 sea surface temperature reconstruction in the Norwegian Sea during the Holocene, Quaternary Sci. Rev., 21, 1385-1394, https://doi.org/10.1016/S0277-3791(01)00096-8, 2002.

De Schepper, S., Head, M. J., and Groeneveld, J.: North Atlantic Current variability through marine isotope stage M2 (circa 3.3 Ma) during the mid-Pliocene, Paleoceanography, 24, PA4206, https://doi.org/10.1029/2008PA001725, 2009.

De Schepper, S., Groeneveld, J., Naafs, B. D. A., Van Renterghem, C., Hennissen, J., Head, M. J., Louwye, S., and Fabian, K.: Northern Hemisphere Glaciation during the Globally Warm Early Late Pliocene, PLoS One, 8, e81508, https://doi.org/10.1371/journal.pone.0081508, 2013.

De Schepper, S., Gibbard, P. L., Salzmann, U., and Ehlers, J.: A global synthesis of the marine and terrestrial evidence for glaciation during the Pliocene Epoch, Earth-Sci. Rev., 135, 83-102, https://doi.org/10.1016/j.earscirev.2014.04.003, 2014.

De Schepper, S., Schreck, M., Beck, K. M., Matthiessen, J., Fahl, K., and Mangerud, G.: Early Pliocene onset of modern Nordic Seas circulation related to ocean gateway changes, Nat. Commun., 6, 1-8, https://doi.org/10.1038/ncomms9659, 2015.

Dowsett, H., Dolan, A., Rowley, D., Moucha, R., Forte, A. M., Mitrovica, J. X., Pound, M., Salzmann, U., Robinson, M., Chandler, M., Foley, K., and Haywood, A.: The PRISM4 (midPiacenzian) paleoenvironmental reconstruction, Clim. Past, 12, 1519-1538, https://doi.org/10.5194/cp-12-1519-2016, 2016.

Driscoll, N. W. and Haug, G. H.: A Short Circuit in thermohaline Circulation: A Cause for Northern Hemisphere Glaciation?, Science, 282, 436-438, https://doi.org/10.1126/science.282.5388.436, 1998.

Eldholm, O., Thiede, J., and Taylor, E.: Site 642: Norwegian Sea, Proc. Ocean Drill. Program, Initial Reports, 104, 53-453, 1987.

Eldrett, J. S., Harding, I. C., Wilson, P. A., Butler, E., and Roberts, A. P.: Continental ice in Greenland during the Eocene and Oligocene, Nature, 446, 176-179, https://doi.org/10.1038/nature05591, 2007.

Fedorov, A. V., Brierley, C. M., Lawrence, K. T., Liu, Z., Dekens, P. S., and Ravelo, A. C.: Patterns and mechanisms of early Pliocene warmth, Nature, 496, 43-49, https://doi.org/10.1038/nature12003, 2013.

Filippova, A., Kienast, M., Frank, M., and Schneider, R. R.: Alkenone paleothermometry in the North Atlantic: A review and synthesis of surface sediment data and calibrations, Geochem. Geophy. Geosy., 17, 1370-1382, https://doi.org/10.1002/2015GC006106, 2016.

Fronval, T. and Jansen, E.: Late Neogene paleoclimates and paleoceanography in the Iceland-Norwegian Sea: evidence from the Iceland and Vøring Plateaus, Proc. Ocean Drill. Program, Sci. Results, 151, 455-468, 1996.

Haug, G. H. and Tiedemann, R.: Effect of the formation of the Isthmus of Panama on Atlantic Ocean thermohaline circulation, Nature, 393, 673-676, https://doi.org/10.1038/31447, 1998.

Haug, G. H., Ganopolski, A., Sigman, D. M., Rosell-Melé, A., Swann, G. E. A., Tiedemann, R., Jaccard, S. L., Bollmann, J., Maslin, M. A., Leng, M. J., and Eglinton, G.: North Pacific seasonality and the glaciation of North America 2.7 million years ago, Nature, 433, 821-825, https://doi.org/10.1038/nature03332, 2005 .
Heinrich, H.: Origin and consequences of cyclic ice rafting in the northeast Atlantic Ocean during the past 130000 years, Quaternary Res., 29, 142-152, 1988.

Herbert, T. D., Lawrence, K. T., Tzanova, A., Peterson, L. C., Caballero-Gill, R., and Kelly, C. S.: Late Miocene global cooling and the rise of modern ecosystems, Nat. Geosci., 9, 843-847, https://doi.org/10.1038/ngeo2813, 2016.

Hilgen, F. J., Lourens, L. J., and Van Dam, J. A.: The Neogene Period, in: The Geologic Time Scale, Elsevier Science Ltd., Boston, USA, 923-978, 2012.

Hill, D. J.: The non-analogue nature of Pliocene temperature gradients, Earth Planet. Sc. Lett., 425, 232-241, https://doi.org/10.1016/j.eps1.2015.05.044, 2015.

Indermühle, A., Stocker, T. F., Joos, F., Fischer, H., Smith, H. J., Wahlen, M., Deck, B., Mastroianni, D., Tschumi, J., Blunier, T., Meyer, R., and Stauffer, B.: Holocene carbon-cycle dynamics based on $\mathrm{CO}_{2}$ trapped in ice at Taylor Dome, Antarctica, Nature, 398, 121-126, https://doi.org/10.1038/18158, 1999.

Jansen, E. and Sjøholm, J.: Reconstruction of glaciation over the past $6 \mathrm{Myr}$ from ice-borne deposits in the Norwegian Sea, Nature, 349, 600-603, https://doi.org/10.1038/349600a0, 1991.

Jansen, E., Sjøholm, J., Bleil, U., and Erichsen, J. A.: Neogene and Pleistocene glaciations in the Northern Hemisphere and Miocene-Pliocene global ice volume fluctuations: Evidence from the Norwegian Sea, in: Geological history of the Polar Oceans, 677-705, available at: http://link.springer.com/chapter/10.1007/ 978-94-009-2029-3_35 (last access: 27 August 2013), 1990.

Jansen, E., Fronval, T., Rack, F., and Channell, J. E. T.: PliocenePleistocene ice rafting history and cyclicity in the Nordic Seas during the last 3.5 Myr, Paleoceanography, 15, 709-721, https://doi.org/10.1029/1999PA000435, 2000.

Japsen, P., Bonow, J. M., Green, P. F., Chalmers, J. A., and Lidmar-Bergström, K.: Elevated, passive continental margins: Long-term highs or Neogene uplifts? New evidence from West Greenland, Earth Planet. Sc. Lett., 248, 330-339, https://doi.org/10.1016/j.epsl.2006.05.036, 2006.

Kameo, K. and Sato, T.: Biogeography of Neogene calcareous nannofossils in the Caribbean and the eastern equatorial Pacific Floral response to the emergence of the Isthmus of Panama, Mar. Micropaleontol., 39, 201-218, https://doi.org/10.1016/S03778398(00)00021-9, 2000.

Karas, C., Nürnberg, D., Bahr, A., Groeneveld, J., Herrle, J. O., Tiedemann, R., and DeMenocal, P. B.: Pliocene oceanic seaways and global climate, Sci. Rep., 7, 39842 , https://doi.org/10.1038/srep39842, 2017.

Kleiven, H. F., Jansen, E., Fronval, T., and Smith, T. M.: Intensification of Northern Hemisphere glaciations in the circum Atlantic region (3.50-2.4 Ma) - ice-rafted detritus evidence, Palaeogeogr. Palaeocl., 184, 213-223, 2002.

Klocker, A., Prange, M., and Schulz, M.: Testing the influence of the Central American Seaway on orbitally forced Northern Hemisphere glaciation, Geophys. Res. Lett., 32, L03703, https://doi.org/10.1029/2004GL021564, 2005.

Knies, J., Mattingsdal, R., Fabian, K., Grøsfjeld, K., Baranwal, S., Husum, K., De Schepper, S., Vogt, C., Andersen, N., Matthiessen, J., Andreassen, K., Jokat, W., Nam, S.-I., and Gaina, C.: Effect of early Pliocene uplift on late Pliocene cooling in the Arctic-Atlantic gateway, Earth Planet. Sc. Lett., 387, 132-144, https://doi.org/10.1016/j.epsl.2013.11.007, 2014a. 
Knies, J., Cabedo-Sanz, P., Belt, S. T., Baranwal, S., Fietz, S., and Rosell-Melé, A.: The emergence of modern sea ice cover in the Arctic Ocean, Nat. Commun., 5, 5608, https://doi.org/10.1038/ncomms6608, 2014b.

Kornilova, O. and Rosell-Melé, A.: Application of microwaveassisted extraction to the analysis of biomarker climate proxies in marine sediments, Org. Geochem., 34, 1517-1523, https://doi.org/10.1016/S0146-6380(03)00155-4, 2003.

Larsen, H. C., Saunders, A. D., Clift, P. D., Beget, J., Wei, W., and Spezzaferri, S.: Seven million years of glaciation in Greenland, Science, 264, 952-955, https://doi.org/10.1126/science.264.5161.952, 1994.

Laskar, J., Robutel, P., Joutel, F., Gastineau, M., Correia, A. C. M., and Levrard, B.: A long-term numerical solution for the insolation quantities of the Earth, Astron. Astrophys., 428, 261-285, https://doi.org/10.1051/0004-6361:20041335, 2004.

Lawrence, K. T., Herbert, T. D., Brown, C. M., Raymo, M. E., and Haywood, A. M.: High-amplitude variations in North Atlantic sea surface temperature during the early Pliocene warm period, Paleoceanography, 24, PA2218, https://doi.org/10.1029/2008PA001669, 2009.

Lisiecki, L. E. and Raymo, M. E.: A Pliocene-Pleistocene stack of 57 globally distributed benthic $\delta^{18} \mathrm{O}$ records, Paleoceanography, 20, PA1003, https://doi.org/10.1029/2004PA001071, 2005.

Locarnini, R. A., Mishonov, A. V., Antonov, J. I., Boyer, T. P., Garcia, H. E., Baranova, O. K., Zweng, M. M., Paver, C. R., Reagan, J. R., Johnson, D. R., Hamilton, M., and Seidov, D.: Temperature, in: World Ocean Atlas 2013. Vol. 1, edited by: Levitus, S. and Mishonov, A., NOAA Atlas NESDIS, Silver Spring, MD, USA, vol. 73, 40 pp., 2013.

Lunt, D. J., Foster, G. L., Haywood, A. M., and Stone, E. J.: Late Pliocene Greenland glaciation controlled by a decline in atmospheric $\mathrm{CO}_{2}$ levels, Nature, 454, 1102-1105, https://doi.org/10.1038/nature07223, 2008.

Macdonald, A. M. and Wunsch, C.: An estimate of global ocean circulation and heat fluxes, Nature, 382, 436-439, https://doi.org/10.1038/382436a0, 1996.

Maier-Reimer, E., Mikolajewicz, U., and Crowley, T. J.: Ocean general circulation model sensitivity experiment with an open Central American isthmus, Paleoceanography, 5, 349-366, 1990.

Marcott, S. A., Clark, P. U., Padman, L., Klinkhammer, G. P., Springer, S. R., Liu, Z., Otto-Bliesner, B. L., Carlson, A. E., Ungerer, A., Padman, J., He, F., Cheng, J., and Schmittner, A.: Ice-shelf collapse from subsurface warming as a trigger for Heinrich events, P. Natl. Acad. Sci. USA, 108, 13415-13419, https://doi.org/10.1073/pnas.1104772108, 2011.

Marincovich, L. and Gladenkov, A. Y.: Evidence for an early opening of the Bering Strait, Nature, 397, 149-151, https://doi.org/10.1038/16446, 1999.

Martínez-Botí, M. A., Foster, G. L., Chalk, T. B., Rohling, E. J., Sexton, P. F., Lunt, D. J., Pancost, R. D., Badger, M. P. S., and Schmidt, D. N.: Plio-Pleistocene climate sensitivity evaluated using high-resolution $\mathrm{CO}_{2}$ records, Nature, 518, 49-54, https://doi.org/10.1038/nature14145, 2015.

Maslin, M. A., Li, X. S., Loutre, M.-F., and Berger, A. L.: The contribution of orbital forcing to the progressive intensification of Northern Hemisphere glaciation, Quaternary Sci. Rev., 17, 411426, https://doi.org/10.1016/S0277-3791(97)00047-4, 1998.
Mauritzen, C.: Production of dense overflow waters feeding the North Atlantic across the Greenland-Scotland Ridge. Part 1: Evidence for a revised circulation scheme, Deep-Sea Res. Pt. I, 43, 807-835, https://doi.org/10.1016/0967-0637(96)00038-6, 1996.

Mudelsee, M. and Raymo, M. E.: Slow dynamics of the Northern Hemisphere glaciation, Paleoceanography, 20, PA4022, https://doi.org/10.1029/2005PA001153, 2005.

Müller, A. and Knies, J.: Trace elements and cathodoluminescence of detrital quartz in Arctic marine sediments - a new ice-rafted debris provenance proxy, Clim. Past, 9, 2615-2630, https://doi.org/10.5194/cp-9-2615-2013, 2013.

Müller, P. J., Kirst, G., Ruhland, G., von Storch, I., and Rosell-Melé, A.: Calibration of the alkenone paleotemperature index $\mathrm{U}_{37}^{K^{\prime}}$ based on core-tops from the eastern South Atlantic and the global ocean $\left(60^{\circ} \mathrm{N}-60^{\circ} \mathrm{S}\right)$, Geochim. Cosmochim. Ac., 62, 17571772, https://doi.org/10.1016/S0016-7037(98)00097-0, 1998.

Osborne, A. H., Newkirk, D. R., Groeneveld, J., Martin, E. E., Tiedemann, R., and Frank, M.: The seawater neodymium and lead isotope record of the final stages of Central American Seaway closure, Paleoceanography, 29, 715-729, https://doi.org/10.1002/2014PA002676, 2014.

Pagani, M., Liu, Z., LaRiviere, J., and Ravelo, A. C.: High Earth-system climate sensitivity determined from Pliocene carbon dioxide concentrations, Nat. Geosci., 3, 27-30, https://doi.org/10.1038/ngeo724, 2010.

Panitz, S., Salzmann, U., Risebrobakken, B., De Schepper, S., and Pound, M. J.: Climate variability and long-term expansion of peatlands in Arctic Norway during the late Pliocene (ODP Site 642, Norwegian Sea), Clim. Past, 12, 1043-1060, https://doi.org/10.5194/cp-12-1043-2016, 2016.

Poore, H. R., Samworth, R., White, N. J., Jones, S. M., and McCave, I. N.: Neogene overflow of Northern Component Water at the Greenland-Scotland Ridge, Geochem. Geophy. Geosy., 7, Q06010, https://doi.org/10.1029/2005GC001085, 2006.

Prahl, F. G. and Wakeham, S. G.: Calibration of unsaturation patterns in long-chain ketone compositions for palaeotemperature assessment, Nature, 330, 367-369, https://doi.org/10.1038/330367a0, 1987.

Ravelo, A. C. and Andreasen, D. H.: Enhanced circulation during a warm period, Geophys. Res. Lett., 27, 1001-1004, https://doi.org/10.1029/1999GL007000, 2000.

Ravelo, A. C., Andreasen, D. H., Lyle, M., Olivarez Lyle, A., and Wara, M. W.: Regional climate shifts caused by gradual global cooling in the Pliocene epoch, Nature, 429, 263-267, https://doi.org/10.1038/nature02567, 2004.

Raymo, M. E., Grant, B., Horowitz, M., and Rau, G. H.: MidPliocene warmth: stronger greenhouse and stronger conveyor, Mar. Micropaleontol., 27, 313-326, 1996.

Risebrobakken, B., Dokken, T. M., Smedsrud, L. H., Andersson, C., Jansen, E., Moros, M., and Ivanova, E. V.: Early Holocene temperature variability in the Nordic Seas: The role of oceanic heat advection versus changes in orbital forcing, Paleoceanography, 26, PA4206, https://doi.org/10.1029/2011PA002117, 2011.

Risebrobakken, B., Andersson, C., De Schepper, S., and Mcclymont, E. L.: Low frequency Pliocene climate variability in the eastern Nordic Seas, Paleoceanography, 31, 1154-1175, https://doi.org/10.1002/2015PA002918, 2016.

Robinson, M. M., Valdes, P. J., Haywood, A. M., Dowsett, H. J., Hill, D. J., and Jones, S. M.: Bathymetric controls on 
Pliocene North Atlantic and Arctic sea surface temperature and deepwater production, Palaeogeogr. Palaeocl., 309, 92-97, https://doi.org/10.1016/j.palaeo.2011.01.004, 2011.

Rosell-Melé, A.: Interhemispheric appraisal of the value of alkenone indices as temperature and salinity proxies in high-latitude locations, Paleoceanography, 13, 694-703, https://doi.org/10.1029/98PA02355, 1998.

Rosell-Melé, A. and Prahl, F. G.: Seasonality of $\mathrm{U}_{37}^{K^{\prime}} \quad$ temperature estimates as inferred from sediment trap data, Quaternary Sci. Rev., 72, 128-136, https://doi.org/10.1016/j.quascirev.2013.04.017, 2013.

Rosell-Melé, A., Carter, J. F., and Eglinton, G.: Distributions of long-chained alkenones and alkyl alkenoates in marine surface sediments from the North East Atlantic, Adv. Org. Geochemistry, 22, 501-509, 1994.

Rosell-Melé, A., Carter, J. F., Parry, A. T., and Eglinton, G.: Determination of the $\mathrm{U}_{37}^{K^{\prime}}$ Index in Geological Samples, Anal. Chem., 67, 1283-1289, 1995.

Ruddiman, W. F., McIntyre, A., Niebler-Hunt, V., and Durazzi, J. T.: Oceanic Evidence for the Mechanism of Rapid Northern Hemisphere Glaciation, Quaternary Res., 13, 33-64, https://doi.org/10.1016/0033-5894(80)90081-2, 1980.

Sarnthein, M., Bartoli, G., Prange, M., Schmittner, A., Schneider, B., Weinelt, M., Andersen, N., and Garbe-Schönberg, D.: Mid-Pliocene shifts in ocean overturning circulation and the onset of Quaternary-style climates, Clim. Past, 5, 269-283, https://doi.org/10.5194/cp-5-269-2009, 2009.

Schreck, M., Meheust, M., Stein, R., and Matthiessen, J.: Response of marine palynomorphs to Neogene climate cooling in the Iceland Sea (ODP Hole 907A), Mar. Micropaleontol., 101, 49-67, https://doi.org/10.1016/j.marmicro.2013.03.003, 2013.

Seki, O., Foster, G. L., Schmidt, D. N., Mackensen, A., Kawamura, K., and Pancost, R. D.: Alkenone and boron-based Pliocene $\mathrm{pCO}_{2}$ records, Earth Planet. Sc. Lett., 292, 201-211, https://doi.org/10.1016/j.epsl.2010.01.037, 2010.

Shackleton, N. J., Backman, J., Zimmerman, H. B., Kent, D. V., Hall, M. A., Roberts, D. G., Schnitker, D., Baldauf, J. G., Desprairies, A., Homrighausen, R., Huddlestun, P., Keene, J. B., Kaltenback, A. J., Krumsiek, K. A. O., Morton, A. C., Murray, J. W., and Westberg-Smith, J.: Oxygen isotope calibration of the onset of ice- rafting and history of glaciation in the North Atlantic rgion, Nature, 307, 620-623, 1984.

Sikes, E. L. and Sicre, M.-A.: Relationship of the tetra-unsaturated $\mathrm{C}_{37}$ alkenone to salinity and temperature: Implications for paleoproxy applications, Geochem. Geophy. Geosy., 3, 1063, https://doi.org/10.1029/2002GC000345, 2002.
Solgaard, A. M., Bonow, J. M., Langen, P. L., Japsen, P., and Hvidberg, C. S.: Mountain building and the initiation of the Greenland ice sheet, Palaeogeogr. Palaeocl., 392, 161-176, https://doi.org/10.1016/j.palaeo.2013.09.019, 2013.

Steph, S., Tiedemann, R., Prange, M., Groeneveld, J., Nürnberg, D., Reuning, L., Schulz, M., and Haug, G. H.: Changes in Caribbean surface hydrography during the Pliocene shoaling of the Central American Seaway, Paleoceanography, 21, PA4221, https://doi.org/10.1029/2004PA001092, 2006.

Steph, S., Tiedemann, R., Prange, M., Groeneveld, J., Schulz, M., Timmermann, A., Nürnberg, D., Rühlemann, C., Saukel, C., and Haug, G. H.: Early Pliocene increase in thermohaline overturning: A precondition for the development of the modern equatorial Pacific cold tongue, Paleoceanography, 25, PA2202, https://doi.org/10.1029/2008PA001645, 2010.

St. John, K. E. K. and Krissek, L. A.: The late Miocene to Pleistocene ice-rafting history of southeast Greenland, Boreas, 31, 28-35, 2002.

Stuiver, M., Reimer, P. J., and Reimer, R. W.: CALIB 7.1 [WWW program], available at: http://calib.org, last access: 18 July 2017.

White, L. F., Bailey, I., Foster, G. L., Allen, G., Kelley, S. P., Andrews, J. T., Hogan, K., Dowdeswell, J. A., and Storey, C. D.: Tracking the provenance of Greenland-sourced, Holocene aged, individual sand-sized ice-rafted debris using the $\mathrm{Pb}$-isotope compositions of feldspars and $40 \mathrm{Ar} / 39 \mathrm{Ar}$ ages of hornblendes, Earth Planet. Sc. Lett., 433, 192-203, https://doi.org/10.1016/j.epsl.2015.10.054, 2016.

Wolf, T. C. W. and Thiede, J.: History of terrigenous sedimentation during the past $10 \mathrm{~m} . \mathrm{y}$. in the North Atlantic (ODP Legs 104 and 105 and DSDP Leg 81), Mar. Geol., 101, 83-102, https://doi.org/10.1016/0025-3227(91)90064-B, 1991.

Wright, J. D. and Miller, K. G.: Control of North Atlantic Deep Water circulation by the Greenland-Scotland Ridge, Paleoceanography, 11, 157-170, https://doi.org/10.1029/95PA03696, 1996.

Zhang, X., Prange, M., Steph, S., Butzin, M., Krebs, U., Lunt, D. J., Nisancioglu, K. H., Park, W., Schmittner, A., Schneider, B., and Schulz, M.: Changes in equatorial Pacific thermocline depth in response to Panamanian seaway closure: Insights from a multi-model study, Earth Planet. Sc. Lett., 317-318, 76-84, https://doi.org/10.1016/j.epsl.2011.11.028, 2012.

Zhang, Z., Nisancioglu, K. H., and Ninnemann, U. S.: Increased ventilation of Antarctic deep water during the warm mid-Pliocene, Nat. Commun., 4, 1499, https://doi.org/10.1038/ncomms2521, 2013. 